\title{
Intraoperative local anaesthesia for reduction of postoperative pain following general anaesthesia for dental treatment in children and adolescents (Review)
}

Parekh S, Gardener C, Ashley PF, Walsh T

Parekh S, Gardener C, Ashley PF, Walsh T.

Intraoperative local anaesthesia for reduction of postoperative pain following general anaesthesia for dental treatment in children and adolescents.

Cochrane Database of Systematic Reviews 2014, Issue 12. Art. No.: CD009742.

DOI: 10.1002/14651858.CD009742.pub2. 
TABLE OF CONTENTS

ABSTRACT 1

PLAIN LANGUAGE SUMMARY

SUMMARY OF FINDINGS

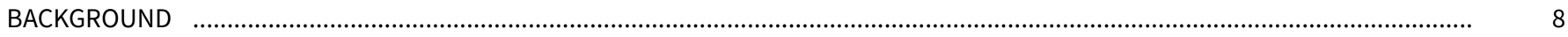

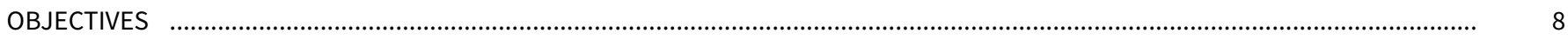

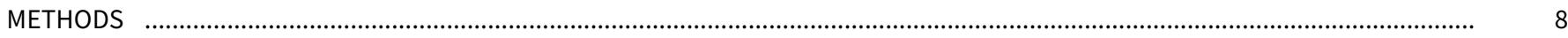

RESULTS

Figure 1. . .

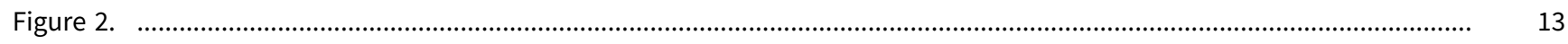

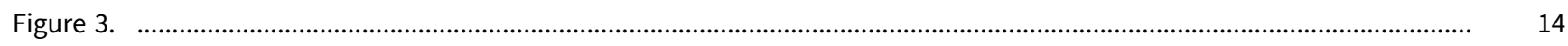

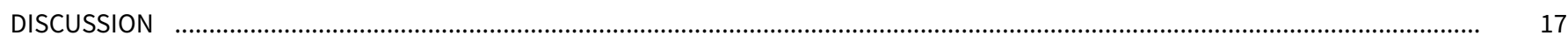

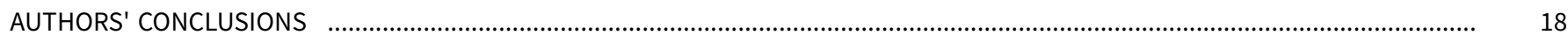

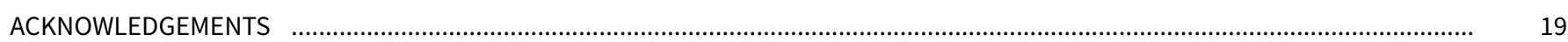

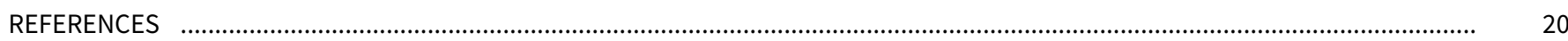

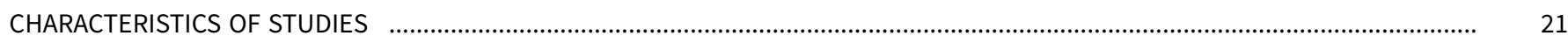

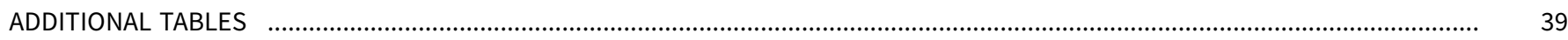

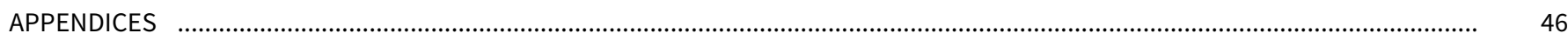

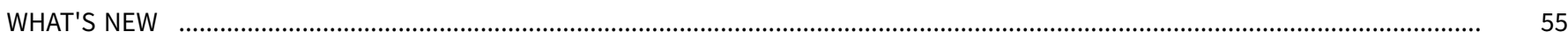

CONTRIBUTIONS OF AUTHORS

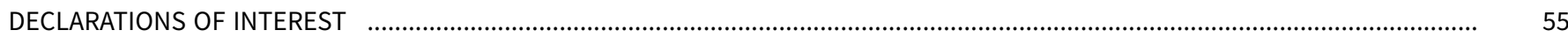

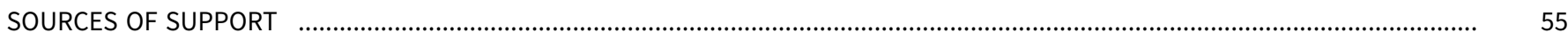

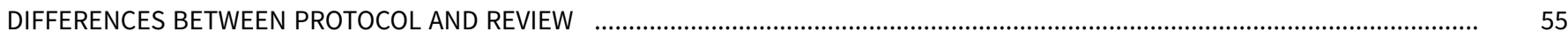

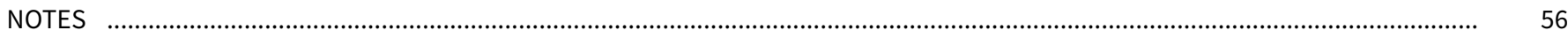

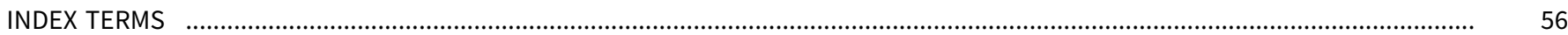


[Intervention Review]

\section{Intraoperative local anaesthesia for reduction of postoperative pain following general anaesthesia for dental treatment in children and adolescents}

Susan Parekh ${ }^{1}$, Collette Gardener ${ }^{1}$, Paul F Ashley ${ }^{1}$, Tanya Walsh ${ }^{2}$

1Unit of Paediatric Dentistry, Department of Craniofacial Growth and Development, UCL Eastman Dental Institute, London, UK. 2Division of Dentistry, School of Medical Sciences, Faculty of Biology, Medicine and Health, The University of Manchester, Manchester, UK

Contact: Susan Parekh, Unit of Paediatric Dentistry, Department of Craniofacial Growth and Development, UCL Eastman Dental Institute, 256 Gray's Inn Road, London, WC1X 8LD, UK. s.parekh@ucl.ac.uk.

Editorial group: Cochrane Oral Health Group.

Publication status and date: Stable (no update expected for reasons given in 'What's new'), published in Issue 11, 2019.

Citation: Parekh S, Gardener C, Ashley PF, Walsh T. Intraoperative local anaesthesia for reduction of postoperative pain following general anaesthesia for dental treatment in children and adolescents. Cochrane Database of Systematic Reviews 2014, Issue 12. Art. No.: CD009742. DOI: 10.1002/14651858.CD009742.pub2.

Copyright @ 2019 The Cochrane Collaboration. Published by John Wiley \& Sons, Ltd.

\section{A B S T R A C T}

\section{Background}

Whilst carrying out dental procedures under general anaesthesia (GA), practitioners routinely give local anaesthetics (LA) intraoperatively to children. Local anaesthetics are used to help manage postoperative pain and reduce bleeding and the physiological response to procedures. Studies of effectiveness of intraoperative LA to date have reported contradictory results.

\section{Objectives}

To assess the effects of intraoperative local anaesthesia for reducing postoperative pain following general anaesthesia for dental treatment in children and young people aged 17 years or younger.

\section{Search methods}

We searched the following electronic databases: the Cochrane Oral Health Group Trials Register; the Cochrane Central Register of Controlled Trials (CENTRAL) (The Cochrane Library, 2013, Issue 12), MEDLINE via OVID (1946 to 02 January 2014), EMBASE via OVID (1980 to 02 January 2014) and Web of Science Conference Proceedings (1990 to 02 January 2014). We searched for ongoing trials in the US National Institutes of Health Register, the metaRegister of Controlled Trials (mRCT) and the International Federation of Pharmaceutical Manufacturers \& Associations (IFPMA) Clinical Trials Portal. We did not place any restrictions on the language or date of publication when searching the electronic databases.

\section{Selection criteria}

Randomised controlled trials in which local anaesthetic was given intraoperatively under general anaesthesia for dental treatment of children and young people aged 17 years or younger.

\section{Data collection and analysis}

We used standard methodological procedures expected by The Cochrane Collaboration. We performed data extraction and assessment of risk of bias independently and in duplicate. We contacted authors to clarify omissions in trial reports. In the 'Summary of findings' tables, we elected to report the outcomes pain, distress, postoperative bleeding, and physiological parameters related to the general anaesthetic, as we considered these to be the outcomes of greatest importance to readers of the review. 


\section{Main results}

We included 14 trials in this review, with 1152 randomised participants. The studies were published between 1990 and 2009 and were conducted in the United Kingdom, Egypt, Saudi Arabia, and the United States. The age of participants ranged from 2 to 40 years. Three studies were at an overall high risk of bias, seven studies were at an unclear risk of bias, and we judged four studies to be at low risk of bias.

The clinical heterogeneity of the included studies precluded pooling of studies in terms of method of administration of LA (e.g., intraligamental injection, infiltration injection, or topical delivery) and variation in the use of supplementary analgesics and follow-up time.

Of the seven studies where administration of LA was by infiltration injection, six studies (very low-quality body of evidence, 542 participants analysed, 1 study had overall high risk of bias, 4 studies had overall unclear risk of bias, 1 study had overall low risk of bias) measured postoperative pain. The results were equivocal. There was a decrease in bleeding and increase in soft tissue damage in the LA groups, but we did not judge this to be clinically significant.

In the 2 studies where administration of LA was by intraligamental injection, there was no difference in mean pain scores, and they did not report any soft tissue damage (very low-quality body of evidence, 115 participants analysed, 1 study had overall high risk of bias, 1 study had overall unclear risk of bias).

One 3-armed study (very low-quality body of evidence, 54 participants analysed, overall high risk of bias) compared the effects of intraligamental and infiltration LA injection with no treatment. There was no evidence of a mean difference in pain, distress, or postoperative anxiety among the three groups.

Four studies (very low-quality body of evidence, 343 participants analysed, 2 studies had overall low risk of bias, 2 studies had overall unclear risk of bias) evaluated the effects of topical LA compared with no treatment or placebo. One study (overall unclear risk of bias) with a no-treatment comparator reported lower mean pain in the LA group; all other studies reported no difference in mean pain scores. Two studies reported on bleeding (overall unclear risk of bias): One study reported a clinically insignificant increase in bleeding with no treatment; the other reported no difference.

None of the studies reported on participant or child satisfaction.

\section{Authors' conclusions}

In this review, it was difficult to reach firm conclusions as to the benefit of using local anaesthetic for dental treatment under general anaesthesia. The information reported in the included studies was comprehensive and applicable to the review question, but ultimately it was not sufficient to address the objective of the review. We were unable to pool the included studies in a meta-analysis because of substantial variation in outcome measures, interventions, and treatment types. The use of supplementary analgesia further obscured the effect of local anaesthetics.

Based on the literature review and the results of this review, we recommend further randomised controlled trials that minimise bias through adequate allocation concealment and blinding of participants and assessors, and assess the effect of intraoperative local anaesthetic on the volume and type of anaesthetic used and on the cardiovascular system in participants receiving supplementary analgesics as well. Researchers should give consideration to the impact of any changes on the health and well-being of the participant and report baseline measures of pain or distress, or both, and preoperative anxiety.

\section{PLAIN LANGUAGE SUMMARY}

\section{Does a local anaesthetic injection in children and young people having dental treatment under general anaesthetic reduce pain} after treatment?

\section{Review question}

Do injections of local anaesthetic given whilst children and young people (aged 17 years or younger) are having dental treatment under general anaesthetic reduce the amount of pain felt afterwards?

\section{Background}

It can be difficult when giving dental treatment to children and young people to do it simply using a local anaesthetic (LA) injection. The problem is often that they are too anxious or that they need a lot of treatment at once: For example, they may need many teeth taken out at the same time. In these circumstances, a dental practitioner commonly uses a general anaesthetic (GA) and administers the treatment in a hospital. In England, there are over 30,000 hospital admissions per year for children who need teeth taken out under a GA.

Problems often arise following this treatment and the most common is pain, the experience of which can cause an emotional as well as a physical response. The experience can make it more difficult for the dental practitioner to give the treatment needed, and it can also cause the child or young person to avoid dental treatment. It is thought that giving LA injections during dental treatment under GA will result in numbness and therefore pain not being felt for a couple of hours, after which time painkillers can control the pain. However, it is not clear what the benefits of using LA in this way are. Some undesired side-effects, such as discomfort; dribbling, and accidental lip biting, have

Intraoperative local anaesthesia for reduction of postoperative pain following general anaesthesia for dental treatment in children and 
been reported. Also, because painkillers are often used as well, the effect of the LA is not clearly defined. Additionally, it is important to clarify the best doses and kind of injections to use to achieve the maximum benefit.

\section{Study characteristics.}

The Cochrane Oral Health Group carried out this review and the evidence on which it is based was up-to-date on 2 January 2014. We included 14 studies, which took place from 1990 to 2009 in the UK, Egypt, Saudi Arabia, and the USA. These included 1152 participants aged from 2 to 40 years.

\section{Key results}

Although the 14 studies included addressed our research question, they differed in the way that they delivered the intervention and what they measured. This meant we could not combine their data in our analyses. The results from individual studies for pain, bleeding, and other adverse effects were uncertain. The use of additional different painkillers may have hidden the effect of the LA.

Further high-quality trials are needed in order to assess the benefits or harms of LA given to children and young people whilst they are receiving dental treatment under GA. Issues that these trials need to address include local side-effects (e.g., excessive dribbling and accidental lip biting), side-effects on other parts of the body (e.g., the heart), participant and parent satisfaction, dosage, type of anaesthetic, and the effects of extra painkillers (e.g., paracetamol).

\section{Quality of the evidence}

The quality of the 14 included studies was variable. We assessed three studies as being at overall risk of high bias, seven at unclear risk of bias, and four at low risk of bias. 


\section{SUMMARY OF FINDINGS}

\section{Summary of findings for the main comparison. Infiltration injection LA versus placebo or no treatment}

Infiltration injection LA compared with placebo or no treatment for reduction of postoperative pain

Participant or population: children undergoing dental extractions under general anaesthetic

Settings: secondary care

Intervention: infiltration injection LA

Comparison: placebo or no treatment

\begin{tabular}{llll}
\hline Outcomes & $\begin{array}{l}\text { Number of partici- } \\
\text { pants } \\
\text { (studies) }\end{array}$ & $\begin{array}{l}\text { Quality of the evi- } \\
\text { dence } \\
\text { (GRADE) }\end{array}$ & Comments \\
\hline $\begin{array}{l}\text { Pain or distress } \\
\text { (self- or investiga- } \\
\text { tor-reported pain } \\
\text { measured postopera- } \\
\text { tively typically up to } \\
\text { discharge) }\end{array}$ & 542 (6 studies) & Very low & $\begin{array}{l}\text { Because of substantial clinical and methodological hetero- } \\
\text { geneity in the studies, we were unable to determine an esti- } \\
\text { mate of effect }\end{array}$ \\
\hline $\begin{array}{l}\text { Bleeding } \\
\text { me }\end{array}$ & 174 (2 studies) & Very low & $\begin{array}{l}\text { Because of substantial clinical and methodological hetero- } \\
\text { geneity in the studies, we were unable to determine an esti- } \\
\text { mate of effect }\end{array}$ \\
\hline $\begin{array}{l}\text { Physiological parame- } \\
\text { ters }\end{array}$ & 148 (2 studies) & Very low & $\begin{array}{l}\text { Because of substantial clinical and methodological hetero- } \\
\text { geneity in the studies, we were unable to determine an esti- } \\
\text { mate of effect }\end{array}$ \\
\hline
\end{tabular}

\footnotetext{
*The basis for the assumed risk (e.g. the median control group risk across studies) is provided in footnotes. The corresponding risk (and its $95 \% \mathrm{Cl}$ ) is based on the assumed risk in the comparison group and the relative effect of the intervention (and its $95 \% \mathrm{Cl}$ ). Cl: confidence interval; LA: = local anaesthetic; RR: risk ratio.
}

GRADE Working Group grades of evidence

High quality: further research is very unlikely to change our confidence in the estimate of effect.

Moderate quality: further research is likely to have an important impact on our confidence in the estimate of effect and may change the estimate.

Low quality: further research is very likely to have an important impact on our confidence in the estimate of effect and is likely to change the estimate.

Very low quality: we are very uncertain about the estimate.

12 studies reported on postoperative pain up to 24 hours after discharge.

2Quality of evidence assessment was downgraded for study limitations, inconsistency of effect, and imprecision. Pooling of studies was precluded by the clinical heterogeneity of the included studies in terms of analgesia (lignocaine plus adrenaline, lignocaine alone, or prilocaine plus felypressin), use of supplementary analgesics, and follow-up time (see Table 3).

\section{Summary of findings 2 . Intraligamental injection LA versus no treatment}

\section{Intraligamental injection LA compared with no treatment for reduction of postoperative pain}

Participant or population: children undergoing dental extractions under general anaesthetic

Settings: secondary care 
Intervention: intraligamental injection LA

Comparison: no treatment

\begin{tabular}{|c|c|c|c|}
\hline Outcomes & $\begin{array}{l}\text { Number of partici- } \\
\text { pants } \\
\text { (studies) }\end{array}$ & $\begin{array}{l}\text { Quality of the evi- } \\
\text { dence } \\
\text { (GRADE) }\end{array}$ & Comments \\
\hline $\begin{array}{l}\text { Pain } \\
\text { (self- or investigator-reported pain } \\
\text { measured postoperatively on re- } \\
\text { gaining consciousness and up to } \\
\text { first hour following extraction) } 1\end{array}$ & 115 ( 2 studies) & $\begin{array}{l}\text { Very low } \\
\oplus \odot \Theta \Theta^{2}\end{array}$ & $\begin{array}{l}\text { Because of substantial clinical and method- } \\
\text { ological heterogeneity in the studies, we were } \\
\text { unable to determine an estimate of effect }\end{array}$ \\
\hline Bleeding & - & - & None of the studies reported on this outcome \\
\hline Physiological parameters & - & - & None of the studies reported on this outcome \\
\hline
\end{tabular}

GRADE Working Group grades of evidence

High quality: further research is very unlikely to change our confidence in the estimate of effect.

Moderate quality: further research is likely to have an important impact on our confidence in the estimate of effect and may change the estimate.

Low quality: further research is very likely to have an important impact on our confidence in the estimate of effect and is likely to change the estimate.

Very low quality: we are very uncertain about the estimate.

11 study also reported on postoperative pain up to 48 hours after discharge.

${ }^{2}$ Quality of evidence assessment was downgraded for study limitations, inconsistency of effect, and imprecision. Pooling of studies was precluded by the clinical heterogeneity of the included studies in terms of analgesia (bupivacaine plus adrenaline or lignocaine plus adrenaline), use of supplementary analgesics, and follow-up time (see Table 4).

\section{Summary of findings 3. Infiltration injection LA versus intraligamental injection LA versus no treatment}

\section{Infiltration injection LA compared with intraligamental injection LA with no treatment for reduction of postoperative pain}

Participant or population: children undergoing dental extractions under general anaesthetic

Settings: secondary care

Intervention: infiltration injection LA, intraligamental LA

Comparison: no treatment

\begin{tabular}{llll}
\hline Outcomes & $\begin{array}{l}\text { Number of partici- } \\
\text { pants } \\
\text { (studies) }\end{array}$ & $\begin{array}{l}\text { Quality of the evi- } \\
\text { dence } \\
\text { (GRADE) }\end{array}$ & Comments \\
\hline $\begin{array}{l}\text { Pain or distress } \\
\begin{array}{l}\text { (Investigator-reported pain mea- } \\
\text { sured postoperatively typically } \\
\text { up to } 30 \text { minutes postoperative- } \\
\text { ly) } 1\end{array}\end{array}$ & Very low & $\begin{array}{l}\text { Because of substantial clinical and methodologi- } \\
\text { cal heterogeneity in the studies, we were unable } \\
\text { to determine an estimate of effect }\end{array}$ \\
\hline
\end{tabular}

Intraoperative local anaesthesia for reduction of postoperative pain following general anaesthesia for dental treatment in children and 
Bleeding

Physiological parameters
None of the studies reported on this outcome

None of the studies reported on this outcome

*The basis for the assumed risk (e.g., the median control group risk across studies) is provided in footnotes. The corresponding risk (and its $95 \% \mathrm{Cl}$ ) is based on the assumed risk in the comparison group and the relative effect of the intervention (and its $95 \% \mathrm{Cl}$ ). Cl: confidence interval; LA: local anaesthetic; RR: risk ratio.

GRADE Working Group grades of evidence

High quality: further research is very unlikely to change our confidence in the estimate of effect.

Moderate quality: further research is likely to have an important impact on our confidence in the estimate of effect and may change the estimate.

Low quality: further research is very likely to have an important impact on our confidence in the estimate of effect and is likely to

change the estimate.

Very low quality: we are very uncertain about the estimate.

11 study reported on postoperative pain on the first evening after discharge.

${ }^{2}$ Quality of evidence assessment was downgraded for study limitations, inconsistency of effect, and imprecision. Single study of lignocaine plus adrenaline LA (see Table 5).

\section{Summary of findings 4. Topical LA versus no treatment or placebo}

\section{Topical LA compared with placebo or no treatment for reduction of postoperative pain}

Participant or population: children undergoing dental extractions under general anaesthetic

Settings: secondary care

Intervention: topical LA

Comparison: placebo or no treatment

\begin{tabular}{|c|c|c|c|}
\hline Outcomes & $\begin{array}{l}\text { Number of partici- } \\
\text { pants } \\
\text { (studies) }\end{array}$ & $\begin{array}{l}\text { Quality of the evi- } \\
\text { dence } \\
\text { (GRADE) }\end{array}$ & Comments \\
\hline $\begin{array}{l}\text { Pain or distress } \\
\text { (self- or investigator-reported pain } \\
\text { measured postoperatively typically } \\
\text { up to discharge) }{ }^{1}\end{array}$ & 343 (4 studies) & 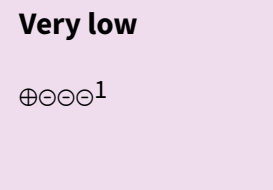 & $\begin{array}{l}\text { Because of substantial clinical and method- } \\
\text { ological heterogeneity in the studies, we were } \\
\text { unable to determine an estimate of effect }\end{array}$ \\
\hline Bleeding & 160 (2 studies) & 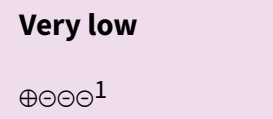 & - \\
\hline Physiological parameters & - & - & None of the studies reported on this outcome \\
\hline
\end{tabular}

GRADE Working Group grades of evidence

High quality: further research is very unlikely to change our confidence in the estimate of effect.

Moderate quality: further research is likely to have an important impact on our confidence in the estimate of effect and may change the estimate.

Low quality: further research is very likely to have an important impact on our confidence in the estimate of effect and is likely to change the estimate. 
Very low quality: we are very uncertain about the estimate.

${ }^{1}$ Quality of evidence assessment was downgraded for study limitations, inconsistency of effect, and imprecision. Pooling of studies was precluded by the clinical heterogeneity of the included studies in terms of analgesia (lignocaine alone (delivered as spray), bupivacaine plus adrenaline (delivered on a dental swab)), use of supplementary analgesics, and follow-up time (see Table 6). 


\section{B A C K G R O U N D}

\section{Description of the condition}

The majority of dental treatment should be carried out in the dental chair using local anaesthesia (LA), but this can be difficult in children, either because the child is too anxious or because they require a significant amount of treatment. General anaesthesia (GA) is commonly used in these circumstances to manage behaviour. In England, there are over 30,000 hospital admissions for dental extractions in children per year (Moles 2009). This procedure is associated with significant postoperative morbidity; one of the most common complaints is postoperative pain (Atan 2004).

Pain is a multidimensional sensory experience that is unpleasant and has strong cognitive and emotional components (PozosGuillen 2007). It may vary in intensity (mild, moderate, or severe), quality (sharp, burning, or dull), duration (transient, intermittent, or persistent), and referral (superficial or deep, localised or diffuse) (Pozos-Guillen 2007). An experience of poorly managed pain related to dental treatment can cause patients to avoid seeking further treatment and make them more difficult to treat (Carr 1999). The management of pain is of particular importance in paediatric dentistry where patients are establishing perceptions of dental treatment.

\section{Description of the intervention}

A local anaesthetic is often injected into the soft tissues surrounding the surgical area before the extraction of teeth under GA. The commonest LA used is $2 \%$ lignocaine with adrenaline as vasoconstrictor, with infiltration injection the most common mode of administration.

\section{How the intervention might work}

Use of LA anaesthetises the soft tissues in the surgical area, by decreasing the permeability of the nerve cell membrane to sodium ions. This produces a reversible loss of function and sensation of nerve conduction impulses near to the site of injection (Sweetman 2006). This effect lasts for one to two hours, meaning that when the child recovers from the GA, their mouth will be numb. As this wears off, pain control can then be managed using oral analgesics. The use of LA might also have other benefits: Use of a vasoconstrictor reduces bleeding, which may help in controlling postoperative haemorrhage and also reduce the physiological response to the surgical procedures, e.g., rise in heart rate. Excessive changes in the physiological responses may necessitate additional administration of the anaesthetic agent, thus, potentially prolonging the GA.

\section{Why it is important to do this review}

Anecdotal observations and studies have suggested that the use of LA in young children could be distressing, uncomfortable, cause excessive dribbling, and maybe also inadvertent lip biting. Patients are often given other analgesics either rectally or intravenously, and it is unclear how much additional pain relief LA provides. Studies to date have reported contradictory results. It is unclear what doses should be given to provide appropriate levels of pain relief and what techniques should be used to administer the LA (e.g., infiltration versus intraligamental).

\section{O B JECTIVES}

To assess the effects of intraoperative local anaesthesia for reducing postoperative pain following general anaesthesia for dental treatment in children and young people aged 17 years or younger.

\section{METHODS}

\section{Criteria for considering studies for this review}

\section{Types of studies}

All parallel group or split mouth randomised controlled trials evaluating intraoperative local anaesthesia for reduction of postoperative pain. Trials comparing active LA intervention with placebo or no treatment were eligible for inclusion, as were trials directly comparing one active LA intervention with another. We only included trials of a split mouth design when the outcomes could be directly attributed to the site of evaluation.

Quasi-randomised trials and cross-over trials were ineligible for inclusion because of the potential for carry over effects and uncertainty over an adequate washout period.

\section{Types of participants}

Participants aged 17 years or younger at the start of treatment having dental treatment including orthodontic treatment, fillings, removal of the nerve from a tooth, or extraction of a tooth under general anaesthesia.

\section{Types of interventions}

Active intervention: any local anaesthetic (including type/dose/ method) given during dental treatment under general anaesthesia.

Comparator: placebo or no local anaesthetic or another local anaesthetic (including type/dose/method).

\section{Types of outcome measures}

\section{Primary outcomes}

1. Postoperative pain or distress measures, or both (either expressed as intensity of pain or presence or absence of pain).

\section{Secondary outcomes}

1. Intraoperative or postoperative bleeding.

2. Cardiac arrhythmia, other cardiac or respiratory events, or both, and type and volume of general anaesthesia drug administered.

3. Incidence of postoperative lip biting or cheek biting, prolonged numbness or allergy.

4. Participant satisfaction.

5. Parental satisfaction.

6. Postoperative anxiety.

\section{Search methods for identification of studies}

\section{Electronic searches}

For the identification of studies for this review, we developed detailed search strategies for each database. We based these on the search strategy developed for MEDLINE (see Appendix 1) but revised appropriately for each database to take account of differences in controlled vocabulary and syntax rules. 
We searched the following databases:

- the Cochrane Oral Health Group Trials Register (to 2 January 2014) (see Appendix 2);

- the Cochrane Central Register of Controlled Trials (CENTRAL; 2013, Issue 12) in The Cochrane Library (see Appendix 3);

- MEDLINE via OVID (1946 to 2 January 2014) (see Appendix 1);

- EMBASE via OVID (1980 to 2 January 2014) (see Appendix 4);

- ISI Web of ScienceConference Proceedings (1990 to 2 January 2014) (see Appendix 5).

There were no restrictions on the language or date of publication. We checked the reference lists of all eligible trials for additional studies.

\section{Searching other resources}

We searched the following databases for ongoing trials up to 2 January 2014:

- the US National Institutes of Health Register (ClinicalTrials.gov) (see Appendix 6);

- the metaRegister of Controlled Trials (mRCT) (see Appendix 7);

- the International Federation of Pharmaceutical Manufacturers \& Associations (IFPMA) Clinical Trials Portal (see Appendix 8),

\section{Handsearching}

We handsearched the following journals:

- International Journal of Paediatric Dentistry (2001 to 19 October 2012)

- Pediatric Dentistry (2001 to 19 October 2012)

- British Dental Journal (2001 19 October 2012)

- Anesthesia Progress (2001 19 October 2012)

- European Journal of Paediatric Dentistry (2001 to 19 October 2012)

- European Archives of Paediatric Dentistry (2001 to 19 October 2012)

\section{Unpublished studies}

We contacted specialists in the field for any unpublished data.

\section{Data collection and analysis}

\section{Selection of studies}

Two review authors independently and in duplicate assessed titles and abstracts for inclusion in the review, resolving disagreements by discussion. We retrieved the full text of the potentially relevant reports and examined them for eligibility. There was no restriction by language on the studies for retrieval. Two review authors independently and in duplicate performed assessment of eligibility. We attempted correspondence with investigators to clarify study eligibility where primary studies did not report information or it was unclear. We made final decisions on study inclusion through discussion and consensus.

\section{Data extraction and management}

Two review authors independently and in duplicate extracted data into a specially designed 'Data extraction form' (see Appendix 9), resolving any disagreements by discussion.
We collected descriptive data where available in addition to that already outlined. We used these data to provide contextual information for the main outcomes, thus, aiding interpretation of results from this review. We give details in Appendix 9; these data include the following:

- the year the study started if not the year it was available;

- the country in which the study was carried out;

- procedure and recovery time;

- anxiety before and after treatment;

- participant satisfaction, parent satisfaction, or both;

- type and volume of general anaesthetic agent administered;

- type and volume of any other analgesic administered immediately prior to or during the general anaesthetic; and

- type of dental treatment.

We did not undertake any data transformations.

\section{Assessment of risk of bias in included studies}

We used the Cochrane 'Risk of bias' tool to assess the methodological quality of the studies as described in the Cochrane Handbook for Systematic Reviews of Interventions (Higgins 2011). The review authors undertook this independently and in duplicate as part of the data extraction process. We assessed the included trials on the following domains.

- sequence generation;

- allocation concealment;

- blinding of participants and personnel;

- blinding of outcome assessor;

- incomplete outcome data;

- selective reporting; and

- other sources of bias.

We tabulated a description of these domains for each included study, along with a judgement of low, high, or unclear risk of bias. We used the Cochrane 'Risk of bias' tool to assess the risk of bias for each study (Higgins 2011).

For the blinding of participants and personnel domain, we made a judgement based on the blinding of the participant only. As the included studies were likely to include no treatment as a comparator, we could not see how personnel could be blinded in such a trial. Furthermore, we judged the lack of blinding of personnel to have limited impact on performance bias.

We undertook a summary assessment of the risk of bias for the primary outcome (across domains) (Higgins 2011). Within a study, we gave a summary assessment of low risk of bias when there was a low risk of bias for all domains, unclear risk of bias when there was an unclear risk of bias for one or more domains, and high risk of bias when there was a high risk of bias for one or more domains.

\section{Measures of treatment effect}

For dichotomous outcomes, the intended measure of treatment effect was the risk ratio; for continuous outcomes, the intended measure of treatment effect was the mean difference for studies reporting an outcome on the same scale, and the standardised mean difference for studies reporting an outcome on different scales. We intended to calculate $95 \%$ confidence intervals 
alongside the treatment effect. However, the studies that reported pain either reported it as a continuous outcome, which was not normally distributed, or as an ordinal outcome with categories ranging from no pain through to severe pain. Where possible, we typically reported summary statistics as medians, range, or interquartile range (IQR). Where papers reported insufficient information to enable the calculation of effect measures, we reported summary measures as a narrative.

\section{Unit of analysis issues}

We planned to use the approaches described in the Cochrane Handbook for Systematic Reviews of Interventions (Higgins 2011).

\section{Dealing with missing data}

We recorded missing data due to attrition as reported in the publication. For parallel group trials, we planned to use the approaches described by Follmann et al (Follmann 1992) to estimate the standard errors (SE) for those studies that did not explicitly report the SE.

\section{Assessment of heterogeneity}

We assessed clinical heterogeneity by examining the characteristics of participants and nature of interventions in each study. We intended to undertake meta-analysis only when studies were of similar comparisons reporting comparable outcome measures. To assess statistical heterogeneity, we planned to use the $\mathrm{Chi}^{2}$ test, to check whether heterogeneity was present, and the $\mathrm{I}^{2}$ statistic, to describe the percentage of the variability in effect estimates due to heterogeneity rather than sampling error (Higgins 2011).

\section{Assessment of reporting biases}

We planned to assess reporting bias through funnel plots and formal testing (Egger 1997) when data from 10 or more studies were available.

\section{Data synthesis}

We undertook a meta-analysis when there were studies of similar comparisons reporting the same outcomes at the same time points. We used risk ratios to combine dichotomous outcomes and (standardised) mean differences for continuous outcomes. For comparisons where we deemed meta-analysis to be inappropriate due to clinical heterogeneity, we reported summary statistics and treatment effects in additional tables.

We based our primary analyses on all the included studies, irrespective of risk of bias.

We analysed and reported split mouth studies taking into account the paired nature of the data.
We reported studies with more than two groups separately.

\section{Subgroup analysis and investigation of heterogeneity}

We planned to assess the impact of the following factors on the effects of the intervention. We had proposed the following subgroup analyses:

1. age ( 0 to 5,6 to 9,10 to 16 years);

2. type of local anaesthetic (lignocaine, articaine, prilocaine, or others);

3. method of administration of local anaesthetic (infiltration, block, or intraligamental); and

4. extent of dental procedure (numbers of extractions or restorations).

\section{Sensitivity analysis}

We planned to undertake a sensitivity analysis, restricting comparisons to studies with low risk of bias and evaluating the robustness of the results to method of analysis (fixed-effect and random-effects model).

\section{'Summary of findings' tables}

We presented 'Summary of findings' tables following GRADE methods. We assessed the quality of the body of evidence by considering the overall risk of bias of the included studies, the directness of the evidence, the inconsistency of the results, the precision of the estimates, and the risk of publication bias. We categorised the quality of the body of evidence of the primary outcome and the secondary outcome of bleeding and physiological parameters under anaesthesia for each comparison as high, moderate, low, or very low. We elected to report these outcomes in the 'Summary of Findings' tables as we considered these to be the outcomes of greatest importance to readers of the review.

\section{RE S U L T S}

\section{Description of studies}

Authors of the following papers provided further information on contact: Anand 2005 and Leong 2007.

\section{Results of the search}

We carried out the search in January 2014. After the removal of duplicates, a total of 569 records were identified through database searching. We assessed 18 full text records for eligibility, of which we excluded 4 , leaving 14 included studies.

We did not identify any ongoing studies.

Figure 1, a flowchart, illustrates the flow of studies. 
Figure 1. Study flow diagram

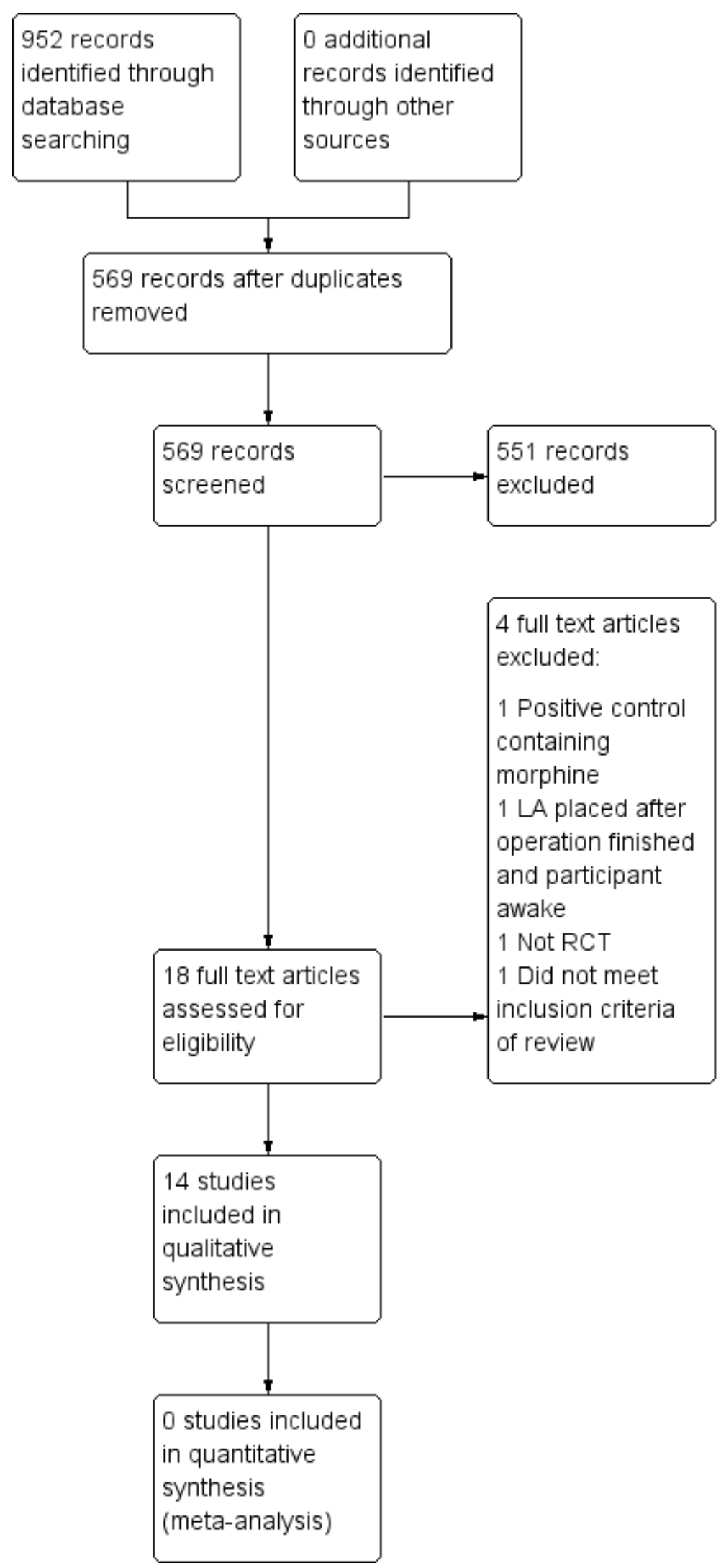




\section{Included studies}

Fourteen studies met the inclusion criteria, and we included them in this review (see the 'Characteristics of included studies' tables). All the studies except for Anand 2005 were of parallel design; the study by Anand 2005 used a split mouth design.

\section{Characteristics of the participants}

One study included participants over 17 year old at the start of the study (Rashad 1990), but as the mean age of participants was 11.4 years (standard deviation (SD) 8.1), we elected to include this study. The remaining studies involved children ranging in age from 2 to 12 years. The number of children randomised in the 14 studies ranged from 27 to 142, with 1152 children randomised in total. The range of dental care provided under general anaesthesia was diverse and ranged from oral surgery procedures (including multiple extractions, impactions, apicectomies, and pulpectomies (Rashad 1990)) to dental rehabilitation of primary teeth (Townsend 2009), and dental extractions of first permanent molars (Anand 2005). The majority of studies involved dental extractions of primary teeth.

\section{Characteristics of the trial setting}

Ten studies were carried out in the UK (Al-Bahlani 2001; Anand 2005; Andrzejowski 2002; Coulthard 2006; Gazal 2004; Leong 2007; McWilliams 2007; Noble 1994; Quirke 2005; Sammons 2007), one was carried out in Egypt (Elhakim 1993), two in the USA (Townsend 2009; Watts 2009), and one in Saudi Arabia (Rashad 1990).

\section{Characteristics of the interventions}

Seven studies gave local anaesthetic (LA) as infiltration compared with either no treatment (Al-Bahlani 2001; McWilliams 2007; Noble 1994; Townsend 2009; Watts 2009) or a placebo (Coulthard 2006; Rashad 1990). Two studies gave LA as intraligamental injection (Anand 2005; Sammons 2007); one study compared infiltration injection with intraligamental injection and no local treatment (Leong 2007). Four studies gave LA topically: Elhakim 1993 compared a lignocaine spray with a paracetamol suppository and no treatment. Andrzejowski 2002, Gazal 2004, and Quirke 2005 all compared bupivacaine, applied using a dental swab, with a saline placebo.

We summarise the composition of the local anaesthetics (LA) used in the studies in Table 1. Lignocaine was the most commonly used LA.

Most of the studies gave additional analgesics alongside the LA either intraoperatively or immediately postoperatively
(Andrzejowski 2002; Anand 2005; Coulthard 2006; Gazal 2004; Leong 2007; McWilliams 2007; Sammons 2007; Townsend 2009; Watts 2009). Doses were not always specified as they were given as part of the general anaesthetic (GA) protocol and not as part of the study.

\section{Characteristics of the outcomes}

All studies except one, Watts 2009, reported some measure of pain or distress, the primary outcome for this review. The included studies employed a variation of measures of pain intensity and distress, either singly or in combination, to measure postoperative pain. The investigators predominantly carried out outcome assessment, with only a small proportion of studies relying on self reporting or parental reporting. We summarise measures used in the included studies to assess pain and distress in Table 2. Where studies measured pain or distress, this was usually on waking, at regular intervals through to discharge, though two studies collected outcome measures for a longer period following the intervention (Leong 2007; Townsend 2009).

Three studies assessed the degree of postoperative bleeding (AlBahlani 2001; Andrzejowski 2002; McWilliams 2007), and four studies assessed the incidence of lip or cheek biting (Anand 2005; Coulthard 2006; Sammons 2007; Townsend 2009).

Two studies assessed physiological parameters related to the general anaesthetic (Rashad 1990; Watts 2009).

Two studies assessed postoperative anxiety using the Venham Picture Scale (Anand 2005; Leong 2007). None of the studies reported on participant or parental satisfaction.

\section{Excluded studies}

We excluded four studies that we considered to be potentially eligible from the review for the following reasons: One study was not a randomised controlled trial (Jürgens 2003); one study did not look at the use of local anaesthesia (Ogg 1983); one study added morphine to the positive control (Bhananker 2008); and one study only applied the local anaesthetic after the participant had woken up (Greengrass 1998).

\section{Risk of bias in included studies}

We based 'Risk of bias' judgements on the information reported in the publication and, where contact with the authors could be made, our correspondence with authors where information was missing or unclear. Figure 2 and Figure 3 illustrate the results of the 'Risk of bias' assessment. 
Figure 2. 'Risk of bias' graph: review authors' judgements about each 'Risk of bias' item presented as percentages across all included studies

Random sequence generation (selection bias)

Allocation concealment (selection bias)

Blinding of participants and personnel (performance bias)

Blinding of outcome assessment (detection bias)

Incomplete outcome data (attrition bias)

Selective reporting (reporting bias)

Other bias

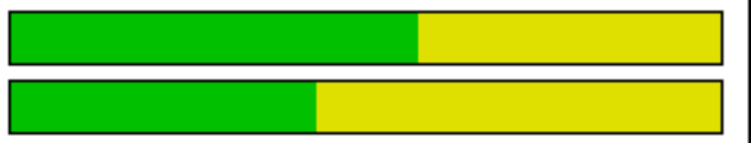

L
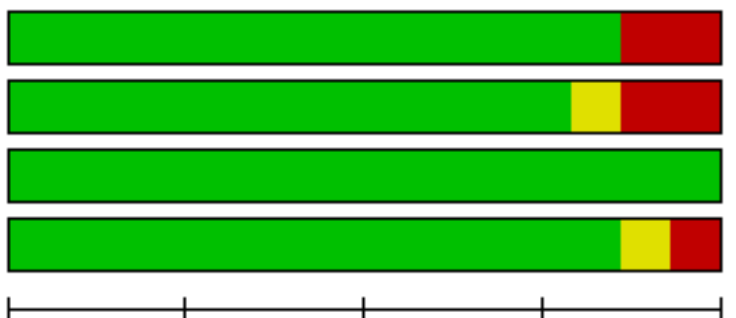

\begin{tabular}{|lllll}
\hline $0 \%$ & & 1 & & 1 \\
& $25 \%$ & $50 \%$ & $75 \%$ & $100 \%$
\end{tabular}

Low risk of bias

Unclear risk of bias

High risk of bias 
Figure 3. 'Risk of bias' summary: review authors' judgements about each 'Risk of bias' item for each included study

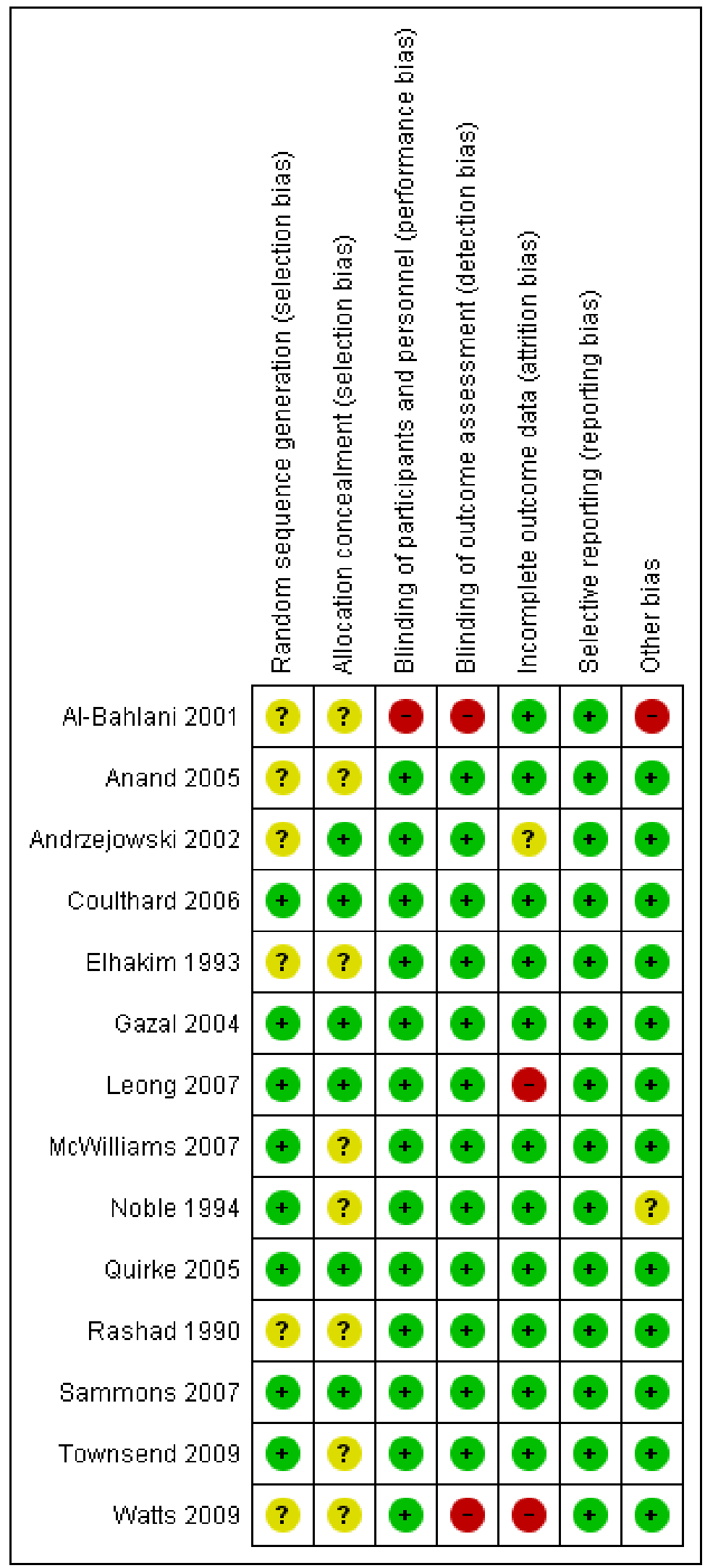




\section{Allocation}

\section{Sequence generation}

Eight studies described adequate methods of sequence generation, and we judged these to be at low risk of bias (Coulthard 2006; Gazal 2004; Leong 2007; McWilliams 2007; Noble 1994; Quirke 2005; Sammons 2007; Townsend 2009). The studies described a range of methods including the use of shuffled envelopes or computer randomisation. Six studies reported sequence generation as 'randomised' but did not report the method of sequence generation (Al-Bahlani 2001; Anand 2005; Andrzejowski 2002; Elhakim 1993; Rashad 1990; Watts 2009). We judged these studies to be at unclear risk of bias for this domain.

\section{Concealment of allocation}

Generally, studies reported concealment of allocation poorly, with only six describing the method of allocation concealment, which typically was sealed envelopes (Andrzejowski 2002; Coulthard 2006; Gazal 2004; Leong 2007; Quirke 2005; Sammons 2007). We judged these studies to be at low risk of bias for this domain. We judged the remaining eight studies as unclear risk of bias for this domain because of insufficient information to enable a judgement to be made.

\section{Blinding}

Blinding of operators was difficult because of the nature of these studies; thus, we judged this domain on the blinding of the participant. Participants were unconscious in all cases so unaware of the LA used. Parents were not allowed in the operating theatre, so were also blinded. In only one study (Al-Bahlani 2001) could the participants have been unblinded to the intervention. Participants were informed beforehand of the likely sensations they would feel postoperatively. This would be dependent on whether they were in the LA or non-LA group. We assessed this study as high risk of performance bias. We judged all other studies to be at low risk of bias.

It would have been possible to perform a blinded outcome assessment of self-reported pain, personnel-reported distress, and clinical measures. Most studies blinded outcome assessors to the intervention, and we judged these studies to be at low risk of detection bias. One study, Al-Bahlani 2001, did not report the blinding of the assessors; this, along with the fact that the participants were also not blinded, meant that we judged this study to be at high risk of detection bias. In another study (Watts 2009), which reported on physiological parameters observed intraoperatively, the researchers felt blinding of assessors to be unnecessary as the outcome measures were supposedly objective. We judged this study to be at high risk of bias as observers could potentially manipulate even these objective measurements to alter the readings.

\section{Incomplete outcome data}

We judged 11 studies to be at low risk of attrition bias as they either clearly described the number of dropouts (no differential dropout) (Coulthard 2006; Gazal 2004; McWilliams 2007; Sammons 2007) or the number of participants reported in the analyses was the same as the number randomised (Al-Bahlani 2001; Anand 2005; Elhakim 1993; Noble 1994; Quirke 2005; Rashad 1990; Townsend 2009). We judged these studies to be at low risk of attrition bias. We judged two studies to be at high risk of attrition bias; in the first (Leong 2007), a significant number of the children did not provide outcome data $(n=29 / 87)$ as they were withdrawn from the study posthoc because they were given a different anaesthetic and analgesic regimen to the rest or had incomplete anaesthetic records. A further 4 children were withdrawn from the study or lost to follow up; the second study, Watts 2009, included all participants in the analysis, but the authors reported "only 46 percent of the study data being complete collections per patient". We judged one study, Andrzejowski 2002, to be at unclear risk of attrition bias where the overall number of dropouts was low (13/120) and the reasons were stated, but the attrition by group was unreported.

\section{Selective reporting}

We did not have access to trial protocols, so we used the information reported in the Methods and Results sections of the trial reports to make a judgement on selective reporting. All studies reported all outcome measures described in the Methods section, and we assessed these to be at low risk of reporting bias.

\section{Other potential sources of bias}

We judged one study, Noble 1994, to be at unclear risk of other potential sources of bias because of baseline imbalance in trial arms in gender and number of extractions. We judged one study, Al-Bahlani 2001, to be at high risk of other potential sources of bias as the authors reduced the observation period for measure of pain (Toddler Preschooler-Postoperative Pain Scale (TPPPS)) from the validated period of 30 minutes to 11 minutes as "no greater discrimination between groups could be determined after this period of observation". We judged all other studies to be at low risk of bias for this domain.

\section{Overall risk of bias}

We judged four studies to be at low risk of bias for all domains (Coulthard 2006; Gazal 2004; Quirke 2005; Sammons 2007), seven studies at unclear risk of bias for at least one domain (Anand 2005; Andrzejowski 2002; Elhakim 1993; McWilliams 2007; Noble 1994; Rashad 1990; Townsend 2009), and three studies at high risk of bias for at least one domain (Al-Bahlani 2001; Leong 2007; Watts 2009).

\section{Effects of interventions}

See: Summary of findings for the main comparison Infiltration injection LA versus placebo or no treatment; Summary of findings 2 Intraligamental injection LA versus no treatment; Summary of findings 3 Infiltration injection LA versus intraligamental injection LA versus no treatment; Summary of findings 4 Topical LA versus no treatment or placebo

There was substantial clinical heterogeneity in the included studies as outlined below.

- Local anaesthetic administration (e.g., intraligamental, infiltration, and topical) varied between studies as did LA composition (Table 1).

- The included studies used 12 different types of outcome measures. These were either simple self-reported or parentreported rating scales, such as the Wong-Baker FACES ${ }^{\circledR}$ Pain Rating Scale, visual analogue scales (VAS), or more complex scales based on aggregating investigator scores of movement, crying, etc., such as the Children's Hospital of Eastern Ontario Pain Scale (CHEOPS) or TPPPS (Table 2). 
- There was variation in the use of supplementary analgesics. Nine out of 14 included studies gave additional analgesics alongside the LA either intraoperatively or immediately postoperatively (Anand 2005; Andrzejowski 2002; Coulthard 2006; Gazal 2004; Leong 2007; McWilliams 2007; Sammons 2007; Townsend 2009; Watts 2009). Doses were not always specified as they were given as part of the GA protocol and not as part of the study.

- There was variation in time of follow up measurement.

We therefore elected to present the results of the studies as a narrative, with summary statistics presented in additional tables, based on the LA given, period of follow up, and the reported outcomes. We aggregated studies that were broadly similar into four groups in an attempt to make sense of the data:

- infiltration injection LA versus either no treatment or placebo;

- intraligamental injection LA versus no treatment;

- infiltration injection LA versus intraligamental injection LA versus no treatment; and

- topical LA versus placebo or no treatment.

Owing to a lack of comparable studies, we were unable to undertake sensitivity analyses. In future updates, should studies allow, we will carry out sensitivity analyses according to risk of bias and robustness of results to statistical model (fixed or random).

\section{Comparison 1: infiltration injection LA versus no treatment or placebo}

Seven studies compared infiltration injection LA with either no treatment (Al-Bahlani 2001; McWilliams 2007; Noble 1994; Townsend 2009; Watts 2009) or a placebo (Coulthard 2006; Rashad 1990) (See Summary of findings for the main comparison).

\section{Lignocaine plus adrenaline}

We included 5 studies, 1 at low risk of bias (Coulthard 2006), 2 at unclear risk of bias (McWilliams 2007; Townsend 2009), and 2 at high risk of bias (Al-Bahlani 2001; Watts 2009), analysing 390 participants in the comparison of LA infiltration and no treatment (4 studies) or placebo (1 study). We present the results of the studies in Table 3. Four studies measure pain, distress, or both, the results of which were equivocal: Two studies that used self-reported measures of pain (Coulthard 2006; Townsend 2009) and one study that used investigator-reported measures of pain (McWilliams 2007) reported no statistically significant differences in pain irrelevant of the intervention. Two studies that used investigator-reported measures of distress reported no statistically significant differences in distress irrelevant of the intervention (Coulthard 2006; Townsend 2009). One study that used investigator-reported measures of pain (Al-Bahlani 2001) reported a statistically significant difference in pain when given LA or no treatment, with greater pain reported for the LA group.

Two studies (Al-Bahlani 2001; McWilliams 2007) reported on postoperative bleeding; both studies reported more bleeding in the no-treatment group compared with the infiltration LA group. Two studies (Coulthard 2006; Townsend 2009) reported on lip or cheek biting, with no statistically significant difference in prevalence. One study, Watts 2009, assessed perioperative physiological parameters 30 seconds after pulpotomy, crown, and extraction. For those children undergoing extraction, the study authors reported a statistically significant difference in mean end tidal $\mathrm{CO} 2$ in favour of infiltration LA. No statistically significant difference in mean heart rate or respiratory rate was observed.

None of the studies reported on patient satisfaction, child satisfaction, or postoperative anxiety.

\section{Lignocaine alone}

We included 1 study (Rashad 1990), at unclear risk of bias, analysing 100 participantsin the comparison of LA infiltration and placebo. The study authors reported a statistically significant difference in the prevalence of postoperative pain, with more participants reporting pain in the placebo group compared with the infiltration LA group. The study authors also reported that the perioperative maximum pulse rate, volume of GA delivered, and incidence of cardiac dysrhythmias was significantly lower in the infiltration LA group. Mean values of end tidal $\mathrm{CO} 2$ were also lower in the placebo group, though this result was not significant (see Table 3).

The study did not report on bleeding, lip biting, participant satisfaction, child satisfaction, or postoperative anxiety.

\section{Prilocaine plus felypressin}

We included 1 study (Noble 1994), at unclear risk of bias, analysing 100 participants in the comparison of LA infiltration and no treatment. The study authors reported statistically significantly higher investigator-reported distress in the infiltration LA group compared with the no-treatment group (see Table 3).

The study did not report bleeding, cardiac events, lip biting, patient satisfaction, child satisfaction, or postoperative anxiety.

\section{Comparison 2: intraligamental injection LA versus no treatment}

Two studies (Anand 2005; Sammons 2007) compared intraligamental injection LA with no treatment (See Summary of findings 2).

\section{Bupivacaine plus adrenaline}

We included 1 split mouth study (Anand 2005), at unclear risk of bias, analysing 30 participants in the comparison of intraligamental LA and no treatment. The study authors reported no difference in the pain on regaining consciousness between the LA side of the mouth compared with the no-treatment side of the mouth (see Table 4). Lip biting and numbness was reported for the intraligamental LA side of the mouth only. The study used the Venham Picture Scale to measure postoperative anxiety, but due to the split mouth study design, we were unable to compare postoperative anxiety between the intraligamental LA and notreatment sides of the mouth.

The study did not report on bleeding, cardiac events, patient satisfaction, or child satisfaction.

\section{Lignocaine plus adrenaline}

We included 1study (Sammons 2007), at low risk of bias, analysing 85 participants in the comparison of intraligamental injection LA and no treatment. The authors reported no statistically significant difference in the self-reported or investigator-reported total pain score in the first hour postoperatively, and no participants reported lip or cheek biting (see Table 4). 
The study did not report on bleeding, cardiac events, patient satisfaction, child satisfaction, or postoperative anxiety.

\section{Comparison 3: infiltration injection LA versus intraligamental injection LA versus no treatment}

\section{Lignocaine plus adrenaline}

We included 1 study (Leong 2007), at high risk of bias, analysing 54 participants in the comparison of infiltration injection LA, intraligamental injection LA, and no treatment (See Summary of findings 3). The authors reported no statistically significant difference in investigator-reported pain or distress up to 30 minutes postoperatively. There was however a statistically significant difference in parent-reported pain on the first night; though, as the median scores for all three groups was zero, there is no indication of which groups differ (see Table 5).

The Venham Picture Scale was used to assess preoperative and postoperative anxiety in 52 children. Mean postoperative anxiety was not statistically significantly different for the three groups.

The study did not report on bleeding, cardiac events, lip or cheek biting, patient satisfaction, or child satisfaction.

\section{Comparison 4: topical LA versus placebo or no treatment}

Four studies delivered LA topically as a spray (Elhakim 1993) or as a dental swab (Andrzejowski 2002; Gazal 2004; Quirke 2005) (See Summary of findings 4).

\section{Lignocaine (delivered as spray)}

We included 1 study (Elhakim 1993), at unclear risk of bias, analysing 40 participants in the comparison of topical LA by a metered spray and no treatment. The reported prevalence of pain up to 60 minutes postoperatively was significantly less in the spray group compared with the group with no intervention (see Table 6). The study authors also noted prolonged postoperative bleeding in the no-treatment group.

The study did not report on cardiac events, lip or cheek biting, patient satisfaction, child satisfaction, or postoperative anxiety.

\section{Bupivacaine plus adrenaline (delivered as dental swab)}

We included 3 studies, 1 at unclear risk of bias (Andrzejowski 2002) and 2 at low risk of bias (Gazal 2004; Quirke 2005), analysing 303 participants in the comparison of topical LA by dental swab with LA and placebo swab. All three studies reported no statistically significant difference in self-reported postoperative pain (Andrzejowski 2002), investigator-reported pain (Quirke 2005), or self-reported distress (Gazal 2004) (see Table 6).

Only one study, Andrzejowski 2002, reported on postoperative bleeding, with the nurse-assessed degree of bleeding deemed 'mild' in both groups.

None of the studies reported on cardiac events, lip or cheek biting, patient satisfaction, child satisfaction, or postoperative anxiety.

\section{DISCUSSION}

\section{Summary of main results}

In this review, it was difficult to reach firm conclusions as to the benefit of using local anaesthetic for dental treatment under general anaesthesia. We were unable to pool the included studies in a meta-analysis because of substantial variation in outcome measures, interventions, and treatment types. The use of supplementary analgesics further obscured the effect of local anaesthetics (LA); differences between LA and no-LA groups were only seen when supplementary analgesics were not given.

\section{Overall completeness and applicability of evidence}

The information reported in the included studies was comprehensive and applicable to the review question, but ultimately not sufficient to address the objective of the review. The age range of participants in the included studies was broad, and whilst the variability in age can be seen as an advantage in terms of applicability, it can complicate outcome assessment as recording pain or distress in younger children is particularly difficult. There was also variability in the dental procedures being carried out, with children having single or multiple extractions of primary teeth or permanent teeth. The interventions evaluated and treatment protocol, i.e., general anaesthetic (GA) used, supplementary analgesia, varied between studies and was not always fully reported. There was baseline imbalance in one study (Noble 1994), which included more males than females in the no-LA group and more extractions in the LA group. This could potentially have distorted the results as extractions may elicit more pain, and there may be a difference in pain reporting between genders (Denning 2000).

\section{Pain assessment}

Pain assessment remains difficult in young children because of their limited ability to understand assessment instructions and to articulate descriptions of their pain. The approach taken by the majority of studies in this review was to look at other possible measures of pain such as participant movement or signs of distress. It is likely that this measure was less sensitive than self-reported measures, which would have been used in older age groups. It is also important to note that very young children might be confused between the discomfort due to the feeling of numbness resulting from local anaesthetic (LA) administration and a feeling of pain.

The baseline anxiety of the child will influence the measurement of pain (Versloot 2008), yet only two of the studies recorded this (Anand 2005; Leong 2007). Ideally, this should always be recorded to either allow sampling of a high- or low-anxiety group or to allow comparison of the effects of preoperative analgesics on postoperative pain in high- and low-anxiety participants.

Studies measured pain at waking or shortly afterwards; follow-up times then varied, with some studies reviewing participants up to several days postoperatively (Anand 2005; Leong 2007). Measuring pain immediately postoperatively may have posed difficulties as participants are likely to be very distressed on waking anyway. It is likely that this further reduced the sensitivity of the measurement. Given that most studies used short-acting local anaesthetics, it is unclear why they assessed pain more than several hours after the procedure. It is interesting to note that one of the studies, Leong 2007 , noted less pain in the intraligamental group on the first night. It is difficult to postulate a physiological reason for this.

One study, Watts 2009, did not record pain or distress as an outcome, but only looked at the physiologic effect of local anaesthetics. We included this study as it provided information on a secondary outcome of the review. 


\section{Analgesics used}

The concomitant use of analgesics will have affected the assessment of the impact of use of local anaesthetic intraoperatively. Of the nine studies that gave preoperative or perioperative supplementary analgesics and assessed pain or distress (Anand 2005; Andrzejowski 2002; Coulthard 2006; Gazal 2004; Leong 2007; Townsend 2009; McWilliams 2007; Rashad 1990; Sammons 2007), it is interesting to note that only one of these studies reported a difference in pain scores between the LA and noLA or placebo groups (Rashad 1990). Of the four studies that did not give preoperative or perioperative supplementary analgesics and assessed pain or distress (Al-Bahlani 2001; Elhakim 1993; Noble 1994; Quirke 2005), two studies reported significantly less prevalence of pain (Elhakim 1993) or levels of distress (Noble 1994), one study reported an increased level of pain in the LA group (AlBahlani 2001), and one study reported no statistically significant difference between pain levels in the LA and placebo groups (Quirke 2005).

Use of analgesics during treatment under general anaesthetic would be considered the norm, as is recommended by the Association of Paediatric Anaesthetists (www.rcoa.ac.uk/ node/2269). It is biologically plausible that their analgesic effect may obscure any additional effect from the local anaesthetic.

\section{Local anaesthetic}

Lignocaine was most commonly used, which is unsurprising as it is the standard drug for dental management of intraoperative pain. Given that the aim of these studies was to look at managing postoperative pain, consideration could be given in future to the use of longer-lasting local anaesthetic agents. However, in young children, this might also increase the risk of lip biting postoperatively. The majority of studies delivered the LA as an infiltration injection, so it is difficult to draw any conclusions as to the comparative effectiveness of other modes of delivery, such as intraligamental injections or topical spray. Three of the studies used bupivacaine delivered topically (Andrzejowski 2002; Gazal 2004; Quirke 2005); none of these studies reported any analgesic effect.

\section{Other effects of local anaesthetic}

Secondary outcomes for this review included other possible effects of local anaesthetic, such as reduction in postoperative bleeding, type and volume of local anaesthesia, cardiac arrhythmias, and increased incidence of lip-biting.

In two studies, use of LA led to a statistically significant reduction in bleeding; however, this was felt to be clinically insignificant (Al-Bahlani 2001; McWilliams 2007). Andrzejowski 2002 reported no difference between groups (no statistical testing). In the two studies that looked at the effect on the general anaesthetic (Rashad 1990; Watts 2009), use of LA resulted in a reduction in the volume of anaesthetic gas given, lower mean pulse rates, lower respiratory rates, a reduction in cardiac arrhythmias, lower end tidal carbon dioxide, and a reduced requirement for the anaesthetist to intervene. Interestingly, in Rashad 1990, analgesics were not given before or during the general anaesthetic, and in Watts 2009, they were only given 30 minutes before the end of the case. This is an area that could be investigated further to firstly determine if these differences can be seen if analgesics are given at induction and secondly to better understand the clinical significance (if any) of these anaesthetic events.
Of the four studies reporting lip biting, two noted a greater incidence of lip biting in the LA group (Coulthard 2006; Townsend 2009). This was not judged to be clinically significant in either study.

\section{Quality of the evidence}

The overall quality of the body of evidence for the outcomes of pain or distress, bleeding, and physiological parameters was very low for all comparisons. We downgraded the quality of evidence because of inconsistency, imprecision, and risk of bias. We believe that the variation between the studies in terms of their protocols is sufficient to justify our decision not to combine any data. The small sample sizes in many of the studies available and the overall risk of bias for studies contributing information to many of the outcomes also impact on our confidence in the results. We are very uncertain about the effect of the intervention for all four comparisons, and the body of evidence does not allow any robust conclusions to be made.

\section{Potential biases in the review process}

When assessing selective reporting bias, we assumed that the studies reported all planned outcomes, based on concordance between the Methods and Results sections of the primary studies. Ideally, it is best to assess selective reporting bias against the study protocol; however, the protocols of the included studies were not publicly available at the time of writing.

We have assumed in McWilliams 2007 that an inconsistency in the CHEOPS score is a reporting error. This may be an incorrect assumption.

\section{Agreements and disagreements with other studies or reviews}

We were unable to source any other systematic reviews on this topic. Guidelines for the management of children referred for dental extractions under general anaesthesia produced by the Association of Paediatric Anaesthetists of Great Britain and Ireland recommend that "Infiltration of a local anaesthetic agent combined with a vasoconstrictor agent may have a role in achieving haemostasis, with possibly some benefit in terms of analgesia in the older child who is able to understand the sensation of numbness" (www.rcoa.ac.uk/node/2269). However, the evidence for this recommendation is grade $\mathrm{B}$, as defined by the Scottish Intercollegiate Guidelines Network (SIGN).

\section{AUTHORS' CONCLUSIONS}

\section{Implications for practice}

In this review, it was difficult to reach firm conclusions as to the benefit of using local anaesthetic for dental treatment under general anaesthesia. The information reported in the included studies was comprehensive and applicable to the review question but ultimately not sufficient to address the objective of the review. We were unable to pool the included studies in a metaanalysis because of substantial variation in outcome measures, interventions, and treatment types. The use of supplementary analgesia further obscured the effect of local anaesthetics.

\section{Implications for research}

Based on the literature review and the results of this review, we suggest the following research recommendations. 
- Further randomised controlled clinical trials (RCTs) need to be conducted to assess the effect of intraoperative local anaesthetic on the volume and type of anaesthetic used and on the cardiovascular system in patients receiving supplementary analgesics as well. Consideration should be given to the impact of any changes on the health and well-being of the patient. These trials should report baseline measures of pain, distress, or both, and preoperative anxiety.
- RCTs should be reported in line with the Consolidated Standards of Reporting Trials (CONSORT) statement for reporting of randomised controlled trials.

- Trial protocols should be made available to facilitate assessment of selective reporting.

\section{ACKNOWLEDGEMENTS}

We would like to thank the Cochrane Oral Health Group editorial team and the referees for their helpful feedback and comments. 


\section{RE F E R E N C E S}

\section{References to studies included in this review}

Al-Bahlani 2001 \{published data only\}

AL-Bahlani S, Sherriff A, Crawford PJM. Tooth extraction, bleeding and pain control. Journal of the Royal College of Surgeons of Edinburgh 2001;46(5):261-4. [PUBMED: 11697691]

\section{Anand 2005 \{published data only\}}

Anand P, Wilson R, Sheehy EC. Intraligamental analgesia for post-operative pain control in children having dental extractions under general anaesthesia. European Journal of Paediatric Dentistry 2005;6(1):10-5. [PUBMED: 15839828]

\section{Andrzejowski 2002 \{published data only\}}

Andrzejowski J, Lamb L. The effect of swabs soaked in bupivacaine and epinephrine for pain relief following simple dental extractions in children. Anaesthesia 2002;57(3):281-3. [PUBMED: 11892639]

\section{Coulthard 2006 \{published data only\}}

Coulthard P, Rolfe S, Mackie IC, Gazal G, Morton M, JacksonLeech D. Intraoperative local anaesthesia for paediatric postoperative oral surgery pain - a randomized controlled trial. International Journal of Oral Maxillofacial Surgery 2006;35(12):1114-9. [PUBMED: 17014994]

Elhakim 1993 \{published data only\}

Elhakim M. Painless dental extraction in children. Anaesthesiologie und Reanimation 1993;18(3):80-2. [PUBMED: 8216665]

\section{Gazal 2004 \{published data only\}}

Gazal G, Bowman R, Worthington HV, Mackie IC. A double-blind randomized controlled trial investigating the effectiveness of topical bupivacaine in reducing distress in children following extractions under general anaesthesia. International Journal of Paediatric Dentistry 2004;14(6):425-31. [PUBMED: 15525311]

\section{Leong 2007 \{published data only\}}

Leong KJ, Roberts GJ, Ashley PF. Perioperative local anaesthetic in young paediatric patients undergoing extractions under outpatient 'short-case' general anaesthesia. A doubleblind randomised controlled trial. British Dental Journal 2007;203(6):E11. [PUBMED: 17694046]

\section{McWilliams 2007 \{published data only\}}

McWilliams PA, Rutherford JS. Assessment of early postoperative pain and haemorrhage in young children undergoing dental extractions under general anaesthesia. International Journal of Paediatric Dentistry 2007;17(5):352-7. [PUBMED: 17683324]

\section{Noble 1994 \{published data only\}}

Noble DW, Raab, GM, MacLean D, MacLachan D. Prilocaine infiltration as postoperative analgesia for children having dental extractions under general anesthesia. Regional Anesthesia 1994;19(2):126-31.
Quirke 2005 \{published data only\}

Quirke W, Bhaskar K, Choonara I. A clinical trial of topical application of bupivacaine to reduce post-operative pain in children following dental extractions. Pediatric and Perinatal Drug Therapy 2005;6(4):197-9.

\section{Rashad 1990 \{published data only\}}

Rashad A, El-Attar A. Cardiac dysrhythmias during oral surgery: effect of combined local and general anaesthesia. British Journal of Oral and Maxillofacial Surgery 1990;28(2):102-4. [PUBMED: 2337559]

\section{Sammons 2007 \{published data only\}}

Sammons HM, Unsworth V, Gray C, Choonara I, Cherrill J, Quirke W. Randmoized controlled trial of the intraligamental use of a local anaesthetic (lignocaine $2 \%$ ) versus controls in paediatric tooth extraction. International Journal of Paediatric Dentistry 2007;17(4):297-303. [PUBMED: 17559458]

\section{Townsend 2009 \{published data only\}}

Townsend JA, Ganzberg S, Thikkurissy S. The effect of local anesthetic on quality of recovery characteristics following dental rehabilitation under general anesthesia in children. Anesthesia Progress 2009;56(4):115-22. [PUBMED: 20020791]

\section{Watts 2009 \{published data only\}}

Watts AK, Thikkurissy S, Smiley M, McTigue DJ, Smith T. Local anesthesia affects physiologic parameters and reduces anesthesiologist intervention in children undergoing general anesthesia for dental rehabilitation. Pediatric Dentistry 2009;31(5):414-9. [PUBMED: 19947137]

\section{References to studies excluded from this review}

Bhananker 2008 \{published data only\}

Bhananker SM, Azavedo LF, Splinter WM. Addition of morphine to local anesthetic infiltration does not improve analgesia after pediatric dental extractions. Paediatric Anaesthesia 2008;18(2):140-4. [PUBMED: 18184245]

\section{Greengrass 1998 \{published data only\}}

Greengrass SR, Andrzejowski J, Ruiz K. Topical bupivacaine for pain control following simple dental extractions. British Dental Journal 1998;184(7):354-5. [PUBMED: 9599891]

\section{Jürgens 2003 \{published data only\}}

Jürgens S, Warwick RS, Inglehearn PJ, Gooneratne DS. Pain relief for paediatric dental chair anaesthesia: current practice in a community dental clinic. International Journal of Paediatric Dentistry 2003;13(2):93-7. [PUBMED: 12605626]

\section{Ogg 1983 \{published data only\}}

Ogg TW, MacDonald IA, Jennings RA, Morrison CG. Day case dental anaesthesia. Evaluation of three methods of anaesthesia.. British Dental Journal 1983;155(1):14-7. [PUBMED: 6577878] 


\section{Additional references}

\section{Atan 2004}

Atan S, Ashley P, Gilthorpe MS, Scheer B, Mason C, Roberts G. Morbidity following dental treatment of children under intubation general anaesthesia in a day-stay unit. International Journal of Paediatric Dentistry 2004;14(1):9-16. [PUBMED: 14706023]

\section{Carr 1999}

Carr DB, Goudas LC. Acute pain. Lancet 1999;353(9169):2051-8. [PUBMED: 10376632]

\section{Denning 2000}

Denning J, Logan H, Southard K, Johnson S, Jakobsen J. Gender differences in response to orthodontic separator placement [abstract]. Journal of Dental Research 2000;79:326.

\section{Egger 1997}

Egger M, Davey Smith G, Schneider M, Minder C. Bias in meta-analysis detected by a simple, graphical test. $B M J$ 1997;315(7109):629-34. [PUBMED: 9310563]

\section{Follmann 1992}

Follmann D, Elliott P, Suh I, Cutler J. Variance imputation for overviews of clinical trials with continuous response. Journal of Clinical Epidemiology 1992;45(7):769-73. [PUBMED: 1619456]

\section{Higgins 2011}

Higgins JPT, Green S (editors). Cochrane Handbook for Systematic Reviews of Interventions Version 5.1.0 [updated March 2011]. The Cochrane Collaboration, 2011. Available from www.cochrane-handbook.org.

\section{Moles 2009}

Moles DR, Ashley P. Hospital admissions for dental care in children: England 1997-2006. British Dental Journal 2009;206(7):E14. [PUBMED: 19330014]

\section{Pozos-Guillen 2007}

Pozos-Guillen A, Martinez-Rider R, Aguirre-Banuelos P, PerezUrizar J. Pre-emptive analgesic effect of tramadol after mandibular third molar extraction: a pilot study. Journal of Oral and Maxillofacial Surgery 2007;65(7):1315-20. [PUBMED: 17577495]

\section{Sweetman 2006}

Sweetman SC. Martindale: The Complete Drug Reference. 5th Edition. London: Pharmaceutical Press, 2006.

\section{Versloot 2008}

Versloot J, Veerkamp JS, Hoogstraten J. Pain behaviour and distress in children during two sequential dental visits: comparing a computerised anaesthesia delivery system and a traditional syringe. British Dental Journal 2008;205(1):E2. [PUBMED: 18493254]

CHARACTERISTICS OF STUDIES

Characteristics of included studies [ordered by study ID]

\section{Al-Bahlani 2001}

\begin{tabular}{ll}
\hline Methods & Study design: 2-arm parallel randomised trial \\
Conducted in: UK & Number of centres: 1 \\
& Setting: dental hospital \\
& Recruitment period: unclear \\
& Funding source: not reported \\
& Inclusion criteria: unclear; medically fit and well \\
& Exclusion criteria: not reported \\
& Number of participants randomised/evaluated: total = 100 (group 1 = 50, group 2 =50) \\
Participants & Age range $=3$ to 5 years \\
\hline Group 1: IFL, 0.5 ml 2\% lignocaine with 1:80,000 adrenaline infiltration per quadrant \\
Group 2: NLA \\
\hline TPPPS and assessment of bleeding through total blood loss per root \\
Measured at 1 minute, 5 to 6 minutes, and 11 minutes postoperatively \\
\hline Outcomes
\end{tabular}


Al-Bahlani 2001 (Continued)

Notes
De-interventions: none reported
There was no sample size calculation
The observation period for the TPPPS was reduced from the validated period of 30 minutes to 11 min-
utes: "no greater discrimination between groups could be determined after this period of observation"

\section{Risk of bias}

\begin{tabular}{|c|c|c|}
\hline Bias & Authors' judgement & Support for judgement \\
\hline \multirow{2}{*}{$\begin{array}{l}\text { Random sequence genera- } \\
\text { tion (selection bias) }\end{array}$} & Unclear risk & Quote: "randomly allocated" \\
\hline & & Comment: The paper did not describe the method of sequence generation \\
\hline $\begin{array}{l}\text { Allocation concealment } \\
\text { (selection bias) }\end{array}$ & Unclear risk & The paper did not describe the method of allocation concealment \\
\hline $\begin{array}{l}\text { Blinding of participants } \\
\text { and personnel (perfor- } \\
\text { mance bias) }\end{array}$ & High risk & $\begin{array}{l}\text { Quote: "Explanation was made to the child of the sensations to be expected } \\
\text { postoperatively either with or without local analgesia" }\end{array}$ \\
\hline All outcomes & & $\begin{array}{l}\text { Comment: The study did not blind participants. It was unclear whether per- } \\
\text { sonnel were blinded as the comparator was no treatment }\end{array}$ \\
\hline $\begin{array}{l}\text { Blinding of outcome as- } \\
\text { sessment (detection bias) } \\
\text { All outcomes }\end{array}$ & High risk & $\begin{array}{l}\text { Outcome assessment was blinded; however, the study did not blind partici- } \\
\text { pants, and this may well have influenced how they behaved postoperatively }\end{array}$ \\
\hline $\begin{array}{l}\text { Incomplete outcome data } \\
\text { (attrition bias) } \\
\text { All outcomes }\end{array}$ & Low risk & The outcome evaluation included all participants \\
\hline $\begin{array}{l}\text { Selective reporting (re- } \\
\text { porting bias) }\end{array}$ & Low risk & $\begin{array}{l}\text { The study reported all outcomes, but it was not clear whether the single sum- } \\
\text { mary distress scores presented were averaged over all } 3 \text { periods of measure- } \\
\text { ment or reported for a single (unspecified) time point }\end{array}$ \\
\hline Other bias & High risk & $\begin{array}{l}\text { The authors reduced the observation period for TPPPS from the validated pe- } \\
\text { riod of } 30 \text { minutes to } 11 \text { minutes as "no greater discrimination between groups } \\
\text { could be determined after this period of observation" }\end{array}$ \\
\hline
\end{tabular}

Anand 2005

Study design: 2-arm split mouth randomised trial
Conducted in: UK
Number of centres: 1
Setting: dental hospital
Recruitment period: unclear
Funding source: not reported

\footnotetext{
Participants

Inclusion criteria: ASA I - II required symmetrical extractions

Exclusion criteria: children in whom LA was contraindicated, children with learning difficulties
} 
Anand 2005 (Continued)

Number of participants randomised/evaluated: total $=30$ (13 males, 17 females)

Mean age $($ years $)=11.3(S D=1.7)$

\begin{tabular}{ll}
\hline Interventions & Group 1: ITR, $0.2 \mathrm{ml}$ bupivacaine (0.5\%) with 1:200000 adrenaline intraligamentary per root \\
& Group 2: NLA \\
\hline Outcomes & Postoperative visual analogue scales and questionnaire \\
& Measured at waking, 2 to 3 days postoperatively \\
\hline Notes & GA procedure: maintained with nitrous oxide/sevoflurane \\
& Co-interventions: Systemic analgesics were given intraoperatively (IV ketorolac, IV alfentanil, supposi- \\
& tory diclofenac sodium). Oral paracetamol or ibuprofen was also given on discharge \\
& Declarations of interest: none reported \\
& There was no sample size calculation
\end{tabular}

\section{Risk of bias}

\begin{tabular}{lll}
\hline Bias & Authors' judgement & Support for judgement \\
\hline $\begin{array}{ll}\text { Random sequence genera- } \\
\text { tion (selection bias) }\end{array}$ & Unclear risk & $\begin{array}{l}\text { Quote: "Each patient acted as his / her own control using a half-mouth study } \\
\text { design. One side of the mouth was randomly selected for administration of ILA } \\
\text { by one of 3 operators" }\end{array}$ \\
& $\begin{array}{l}\text { Comment: The paper did not state the method of sequence generation } \\
\end{array}$
\end{tabular}

\begin{tabular}{|c|c|c|}
\hline $\begin{array}{l}\text { Allocation concealment } \\
\text { (selection bias) }\end{array}$ & Unclear risk & The paper did not describe the method of allocation concealment \\
\hline $\begin{array}{l}\text { Blinding of participants } \\
\text { and personnel (perfor- } \\
\text { mance bias) }\end{array}$ & Low risk & $\begin{array}{l}\text { Quote: "The same operator who administered the LA performed all the dental } \\
\text { extractions" }\end{array}$ \\
\hline All outcomes & & Comment: The study blinded participants \\
\hline
\end{tabular}

\begin{tabular}{|c|c|c|}
\hline \multirow[t]{2}{*}{$\begin{array}{l}\text { Blinding of outcome as- } \\
\text { sessment (detection bias) } \\
\text { All outcomes }\end{array}$} & Low risk & $\begin{array}{l}\text { Quote: "...keeping the principal investigator blind to the side of analgesia" } \\
\text { Quote: "The principal investigator carried out all postoperative assessments } \\
\text { and interviews" }\end{array}$ \\
\hline & & Comment: The study blinded assessors \\
\hline
\end{tabular}

Incomplete outcome data Low risk The outcome evaluation included all participants

(attrition bias)

All outcomes

\begin{tabular}{lll}
\hline $\begin{array}{l}\text { Selective reporting (re- } \\
\text { porting bias) }\end{array}$ & Low risk & The study reported all expected outcomes \\
\hline Other bias & Low risk & There was no other apparent bias \\
\hline
\end{tabular}

Andrzejowski 2002

Methods Study design: 2-arm parallel randomised trial

Intraoperative local anaesthesia for reduction of postoperative pain following general anaesthesia for dental treatment in children and 
Andrzejowski 2002 (Continued)

Conducted in: UK

Number of centres: 1

Setting: dental hospital

Recruitment period: unclear

Funding source: not reported

Participants
Bs)
Exclusion criteria: not reported
Number of participants randomised: total = 133 (unclear how many per group)
Number of participants evaluated: total = 120 (unclear how many per group)
Group 1: mean age (years) $=7$
Group 2: mean age (years) $=6$

Interventions

Group 1: 0.25 bupivacaine with 1:200000 adrenaline topical (swab)

Group 2: saline topical (swab)

\begin{tabular}{ll}
\hline Outcomes & 4-point pain scale recorded by nurse and participant \\
& Assesment of intraoperative bleeding by nurse (none, mild, moderate) \\
\hline Notes & GA procedure: induced and maintained with nitrous oxide/sevoflurane \\
Co-interventions: All participants received rectal diclofenac & Declarations of interest: none reported \\
& There was a sample size calculation
\end{tabular}

\section{Risk of bias}

\begin{tabular}{lll}
\hline Bias & Authors' judgement & Support for judgement \\
\hline $\begin{array}{l}\text { Random sequence genera- } \\
\text { tion (selection bias) }\end{array}$ & Unclear risk & $\begin{array}{l}\text { Quote: "Randomisation was achieving random numbers and a sealed enve- } \\
\text { lope technique" } \\
\end{array}$ \\
& Comment: The paper did not describe the method of sequence generation \\
\hline
\end{tabular}

\begin{tabular}{ll}
\hline $\begin{array}{l}\text { Allocation concealment } \\
\text { (selection bias) }\end{array}$ & Low risk \\
& $\begin{array}{l}\text { Quote: "Randomisation was achieving random numbers and a sealed enve- } \\
\text { lope technique" }\end{array}$ \\
Comment: An anaesthetist prepared the treatment
\end{tabular}

\begin{tabular}{ll}
\hline $\begin{array}{l}\text { Blinding of participants } \\
\text { and personnel (perfor- }\end{array}$ & Quote: "double blind" \\
mance bias) & \\
All outcomes & $\begin{array}{l}\text { Comment: The study blinded participants. This was a placebo-controlled trial, } \\
\text { which we assume blinded personnel given that an anaesthetist prepared treat- } \\
\text { ment }\end{array}$
\end{tabular}

Blinding of outcome as- Low risk sessment (detection bias)

Quote: "All recordings and observations were made by the same nurse, who was unaware of which solution the patient had received"

All outcomes 
Andrzejowski 2002 (Continued)

Incomplete outcome data Unclear risk Quote: "13 of these were too young to be able to self-score their postoperative (attrition bias) pain, so were not included in the final results"

All outcomes

Comment: The overall number of dropouts was low (13/120), and the study stated reasons, but attrition in each group was unclear

Selective reporting (re- Low risk The study reported all expected outcomes
porting bias)

Other bias Low risk There was no other apparent bias

\begin{tabular}{|c|c|}
\hline \multirow[t]{6}{*}{ Methods } & Study design: 2-arm parallel randomised trial \\
\hline & Conducted in: UK \\
\hline & Number of centres: 1 \\
\hline & Setting: dental hospital \\
\hline & Recruitment period: unclear \\
\hline & Funding source: not reported \\
\hline \multirow[t]{7}{*}{ Participants } & Inclusion criteria: extraction of 1 to 10 teeth, ASA I to II, informed consent \\
\hline & Exclusion criteria: hypersensitivity to local anaesthetic or painkillers \\
\hline & Number of participants randomised: total $=142($ group $1=70$, group $2=71)$ \\
\hline & Number of participants evaluated: total = 139 (group $1=70$, group $2=69$ ) \\
\hline & Group 1: median age (years) $=6$ \\
\hline & Group 2: median age (years) $=6$ \\
\hline & Age range $=4$ to 12 years \\
\hline \multirow[t]{2}{*}{ Interventions } & Group 1: IFL 2 ml 2\% lidocaine with 1:200,000 adrenaline \\
\hline & Group 2: IFL 2 ml $0.9 \%$ sodium chloride \\
\hline \multirow[t]{2}{*}{ Outcomes } & 5-category scale of behavioural distress and FACES ${ }^{\circledR}$ Pain Scale \\
\hline & Measured at waking, 30 minutes, and 24 hours \\
\hline \multirow[t]{4}{*}{ Notes } & GA Procedure: induced with propofol, maintained with nitrous oxide/sevoflurane \\
\hline & Co-interventions: All participants were given EMLA and $15 \mathrm{mg} / \mathrm{kg}$ acetaminophen elixir preoperatively \\
\hline & Declarations of interest: none reported \\
\hline & There was a sample size calculation \\
\hline
\end{tabular}

\section{Risk of bias}

Bias Authors' judgement Support for judgement


Coulthard 2006 (Continued)
Random sequence genera- Low risk
Quote: "...a computer generated randomisation code"
tion (selection bias)
Comment: The study stated the method of sequence generation

\begin{tabular}{ll}
\hline $\begin{array}{l}\text { Allocation concealment } \\
\text { (selection bias) }\end{array}$ & Low risk \\
& $\begin{array}{l}\text { Quote: "...opaque sealed envelopes that were opened on intravenous induc- } \\
\text { tion of general anaesthesia by the surgeon" }\end{array}$ \\
& $\begin{array}{l}\text { Comment: The surgeon opened a concealed opaque envelope following intra- } \\
\text { venous induction of anaesthesia }\end{array}$
\end{tabular}

\begin{tabular}{ll}
\hline $\begin{array}{l}\text { Blinding of participants } \\
\text { and personnel (perfor- }\end{array}$ & Low risk \\
mance study blinded participants. This was a placebo-controlled trial, but the \\
surgeon opened an envelope with allocation for each participant
\end{tabular}
mance bias)

All outcomes

\begin{tabular}{|c|c|c|}
\hline \multirow{2}{*}{$\begin{array}{l}\text { Blinding of outcome as- } \\
\text { sessment (detection bias) } \\
\text { All outcomes }\end{array}$} & Low risk & $\begin{array}{l}\text { Quote: "The research nurse did not enter the operating theatre and was blind } \\
\text { to the group allocation" }\end{array}$ \\
\hline & & Comment: The research nurse measured postoperative pain and distress \\
\hline
\end{tabular}

\begin{tabular}{lll}
\hline $\begin{array}{l}\text { Incomplete outcome data } \\
\text { (attrition bias) } \\
\text { All outcomes }\end{array}$ & Low risk & $\begin{array}{l}\text { Data were incomplete for } 3 \text { children (3/139), who were not included in the } \\
\text { analysis }\end{array}$ \\
\hline $\begin{array}{l}\text { Selective reporting (re- } \\
\text { porting bias) }\end{array}$ & Low risk & The study reported all expected outcomes \\
\hline Other bias & Low risk & There was no other apparent bias \\
\hline
\end{tabular}

Elhakim 1993

\begin{tabular}{l} 
Study design: 3-arm parallel randomised trial \\
Conducted in: Egypt \\
Number of centres: 1 \\
Setting: unclear \\
Recruitment period: unclear \\
Funding source: not reported \\
\hline
\end{tabular}

\begin{tabular}{|c|c|}
\hline \multirow[t]{6}{*}{ Participants } & Inclusion/exclusion criteria not specified. ASA I \\
\hline & $\begin{array}{l}\text { Number of participants randomised/evaluated: total }=60 \text { (group } 1=20 \text { (11 male, } 9 \text { female), group } 2= \\
20(12 \text { male, } 8 \text { female), group } 3=20 \text { (9 male, } 11 \text { female) })\end{array}$ \\
\hline & Group 1: mean age (years) = $6.1(S D 2.4)$ \\
\hline & Group 2: mean age (years) = $5.1(S D 1.9)$ \\
\hline & Group 3: mean age (years) = $5.2($ SD 1.6) \\
\hline & Age range $=4$ to 11 years \\
\hline
\end{tabular}

Interventions

Group 1: $4 \mathrm{mg} / \mathrm{kg}$ lignocaine via metered spray

Group 2: $10 \mathrm{mg} / \mathrm{kg}$ paracetamol suppository 
Elhakim 1993 (Continued)

$$
\text { Group 3: no analgesia }
$$

\begin{tabular}{ll} 
Outcomes & Pain assessed as either present or not \\
& Measured at 15 minutes, 30 minutes, and 60 minutes \\
\hline Notes & GA procedure: induced with propofol or nitrous oxide/halothane \\
Co-interventions: none reported \\
Declarations of interest: none reported \\
There was no sample size calculation
\end{tabular}

\section{Risk of bias}

\begin{tabular}{|c|c|c|}
\hline Bias & Authors' judgement & Support for judgement \\
\hline $\begin{array}{l}\text { Random sequence genera- } \\
\text { tion (selection bias) }\end{array}$ & Unclear risk & $\begin{array}{l}\text { Quote: "The children were allocated randomly" } \\
\text { Comment: The paper did not describe the method of sequence generation }\end{array}$ \\
\hline $\begin{array}{l}\text { Allocation concealment } \\
\text { (selection bias) }\end{array}$ & Unclear risk & Comment: The paper did not describe the method of allocation concealment \\
\hline $\begin{array}{l}\text { Blinding of participants } \\
\text { and personnel (perfor- } \\
\text { mance bias) } \\
\text { All outcomes }\end{array}$ & Low risk & $\begin{array}{l}\text { Comment: The study blinded participants. Blinding of personnel was unre- } \\
\text { ported }\end{array}$ \\
\hline $\begin{array}{l}\text { Blinding of outcome as- } \\
\text { sessment (detection bias) } \\
\text { All outcomes }\end{array}$ & Low risk & $\begin{array}{l}\text { Quote: "The patients were assessed by a single trained observer (blind to the } \\
\text { anaesthetic technique)" } \\
\text { Comment: The assessor was blinded }\end{array}$ \\
\hline $\begin{array}{l}\text { Incomplete outcome data } \\
\text { (attrition bias) } \\
\text { All outcomes }\end{array}$ & Low risk & The outcome evaluation included all participants \\
\hline $\begin{array}{l}\text { Selective reporting (re- } \\
\text { porting bias) }\end{array}$ & Low risk & The study reported all expected outcomes \\
\hline Other bias & Low risk & There was no other apparent bias \\
\hline
\end{tabular}

\section{Gazal 2004}

$\begin{array}{ll}\text { Methods } & \text { Study design: } 2 \text {-arm parallel randomised trial } \\ \text { Conducted in: UK } \\ \text { Number of centres: } 1 \\ \text { Setting: dental hospital } \\ \text { Recruitment period: unclear } \\ \text { Funding source: not reported }\end{array}$


Exclusion criteria: known allergy to LA or paracetamol, refused preoperative dose paracetamol, too distressed to be included

Number of participants randomised: total $=139$ (group $1=69$, group $2=70)$

Number of participants evaluated: total = 135 (group 1 = 68 (36 male, 32 female), group $2=67$ (33 male, 34 female))

Group 1: mean age (years) $=5.9(S D 2.16)$

Group 2: mean age (years) $=5.9(S D 2.24)$

Age range $=2$ to 12 years

\begin{tabular}{ll}
\hline Interventions & Group 1: $0.25 \%$ bupivacaine with 1:4000 adrenaline topical (swab) \\
& Group 2: saline \\
\hline Outcomes & Five-face scale of distress \\
& Measured preoperatively, on waking, and at 15 minutes \\
\hline Notes & GA procedure: induced with propofol, maintained with nitrous oxide/enflurane \\
& Co-interventions: All participants received preoperative paracetamol $15 \mathrm{mg} / \mathrm{kg}$ \\
& Declarations of interest: none reported \\
There was a sample size calculation
\end{tabular}

\section{Risk of bias}

Bias Authors' judgement Support for judgement

Random sequence genera- Low risk Quote: "A statistician randomly allocated the sequence of patient identity tion (selection bias) numbers to either a test or control group using computer generated random numbers"

Comment: The paper stated the method of sequence generation

\begin{tabular}{|c|c|c|}
\hline $\begin{array}{l}\text { Allocation concealment } \\
\text { (selection bias) }\end{array}$ & Low risk & $\begin{array}{l}\text { An independent party allocated treatment using numbered, opaque sealed en- } \\
\text { velopes }\end{array}$ \\
\hline
\end{tabular}

\begin{tabular}{ll}
\hline $\begin{array}{l}\text { Blinding of participants } \\
\text { and personnel (perfor- }\end{array}$ & Quote: "The patient and the dentist carrying out the assessment were blind as \\
to which group the child had been allocated"
\end{tabular}

mance bias)

All outcomes

\begin{tabular}{|c|c|c|}
\hline $\begin{array}{l}\text { Blinding of outcome as- } \\
\text { sessment (detection bias) } \\
\text { All outcomes }\end{array}$ & Low risk & $\begin{array}{l}\text { Quote: "The patient and the dentist carrying out the assessment were blind as } \\
\text { to which group the child had been allocated" }\end{array}$ \\
\hline
\end{tabular}

\begin{tabular}{lll}
\hline $\begin{array}{l}\text { Incomplete outcome data } \\
\text { (attrition bias) } \\
\text { All outcomes }\end{array}$ & Low risk & $\begin{array}{l}\text { The number of dropouts was similar across groups (1/69 in the LA group, 3/70 } \\
\text { in the placebo group), but reasons were not given }\end{array}$ \\
\hline $\begin{array}{l}\text { Selective reporting (re- } \\
\text { porting bias) }\end{array}$ & Low risk & The study reported all expected outcomes \\
\hline Other bias & Low risk & There was no other apparent bias \\
\hline
\end{tabular}


Leong 2007

Study design: 3 -arm parallel randomised trial
Conducted in: UK
Number of centres: 1
Setting: dental hospital
Recruitment period: 2002 to 2003
Funding source: not reported

Participants

Inclusion criteria: parent/guardian who consented to the study and the use of analgesic suppositories, could communicate well in English, and were contactable by telephone for 3 consecutive nights

Exclusion criteria: children who required extraction of only anterior teeth; children who were already in acute pain and had a known medical history of bleeding disorder and hypersensitivity to lidocaine, diclofenac, and paracetamol

Number of participants randomised: total $=87$ (group $1=29$, group $2=29$, group $3=29$ )

Number of participants evaluated: total $=54$ (group $1=18$, group $2=17$, group $3=19$ )

Group 1: median age $=4.5$ years $($ range $=2.6$ to 5.8$)$

Group 2: median age $=4.7$ years $($ range $=2.9$ to 5.8$)$

Group 3: median age $=4.4$ years $($ range $=2.7$ to 6.0 )

Groups were comparable at baseline with respect to age, weight, and number of extractions

Group 1: NLA $(n=29)$ : no perioperative local anaesthetic
Group 2: IFL $(n=29)$ : infiltration injection $0.5 \mathrm{ml} 2 \%$ lignocaine with 1:80,000 adrenaline infiltration per
quadrant
Group 3: ITR $(n=29)$ : intraligamental injection $0.2 \mathrm{ml} 2 \%$ lignocaine with 1:80,000 adrenaline intraliga-
mentary per tooth

Outcomes

Postoperative pain score using STPPPS supplemented with the MPDS

STPPPS measured at waking, 30 minutes, 1 day, 2 days, and 3 days

MPDS measured at waking, 15 minutes, and 30 minutes

Postoperative anxiety scale using the Venham Picture Scale 10 to 15 minutes after arrival into the recovery ward

Notes

Gas induction

Co-interventions: All groups received suppositories after induction (diclofenac sodium, paracetamol, or both)

Declarations of interest: none reported

There was no sample size calculation

\section{Risk of bias}

Bias Authors' judgement Support for judgement


Leong 2007 (Continued)

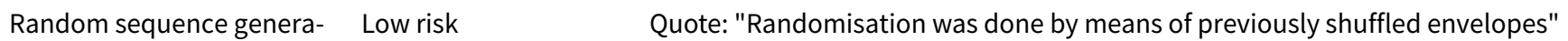
tion (selection bias)

Comment: The paper stated the method of sequence generation

\begin{tabular}{ll}
\hline $\begin{array}{l}\text { Allocation concealment } \\
\text { (selection bias) }\end{array}$ & Low risk \\
& $\begin{array}{l}\text { 'Sealed envelopes' were used, but the paper did not indicate whether they } \\
\text { were sequentially numbered or opaque }\end{array}$ \\
& $\begin{array}{l}\text { Note: For a judgement of low risk of bias, this should be 'sequentially num- } \\
\text { bered, opaque, sealed envelopes' }\end{array}$
\end{tabular}

\begin{tabular}{|c|c|c|}
\hline $\begin{array}{l}\text { Blinding of participants } \\
\text { and personnel (perfor- }\end{array}$ & Low risk & $\begin{array}{l}\text { Operators performing the extractions were aware of the treatment allocation. } \\
\text { The study blinded participants }\end{array}$ \\
\hline
\end{tabular}

mance bias)

All outcomes

\begin{tabular}{|c|c|c|}
\hline $\begin{array}{l}\text { Blinding of outcome as- } \\
\text { sessment (detection bias) }\end{array}$ & Low risk & $\begin{array}{l}\text { Quote: "Both the researcher, and the parents/ guardians were blind to the } \\
\text { technique of perioperative LA" }\end{array}$ \\
\hline All outcomes & & Comment: The study blinded the outcome assessor \\
\hline
\end{tabular}

\begin{tabular}{ll}
\hline $\begin{array}{l}\text { Incomplete outcome data } \\
\text { (attrition bias) } \\
\text { All outcomes }\end{array}$ & $\begin{array}{l}\text { Quote: "Twenty five children received a different analgesic suppository and } \\
\text { anaesthetic agent, four withdrew form the study and four had an incomplete } \\
\text { record of their anaesthetic sheet" }\end{array}$ \\
& $\begin{array}{l}\text { Comment: A significant number of the children did not provide outcome data } \\
(\mathrm{n}=29 / 87) \text { as they were withdrawn from the study posthoc because they were } \\
\text { given a different anaesthetic and analgesic regimen to the rest or had incom- } \\
\text { plete anaesthetic records. A further } 4 \text { children were withdrawn from the study } \\
\text { or lost to follow up }\end{array}$
\end{tabular}

\begin{tabular}{lll}
$\begin{array}{l}\text { Selective reporting (re- } \\
\text { porting bias) }\end{array}$ & Low risk & The study reported all expected outcomes \\
\hline Other bias & Low risk & There was no other apparent bias \\
\hline
\end{tabular}

McWilliams 2007

Study design: 2-arm parallel randomised trial
Conducted in: UK
Number of centres: 1
Setting: day surgery unit, Royal Infirmary
Recruitment period: 2004 to 2006
Funding source: not reported
Inclusion criteria: children aged less than 6 years admitted to the day surgery unit for extraction of de-
ciduous posterior teeth under general anaesthesia
Exclusion criteria: children with severe learning difficulties or communication disorders, such as
autism; those with bleeding disorders or who were receiving systemic anticoagulants or who were giv-
en a sedative preoperative medication; children having deciduous incisor extractions; children or par-
ents who expressed a preference for or against the use of local anaesthetic

Number of participants randomised: total $=85$ (group $1=45$, group $2=40$ ) 
McWilliams 2007 (Continued)

Number of participants evaluated: total $=76$ (group $1=38$, group $2=38$ )

Group 1: median age $=5.2$ years $($ range IQR $=4.2$ to 5.7 )

Group 2: median age $=4.9$ years $($ range IQR $=4.1$ to 5.4 )

Groups were comparable at baseline with respect to age and number of extractions

\begin{tabular}{ll}
\hline Interventions & Group 1: IFL 4\% lignocaine with 1:80000 adrenaline infiltration \\
& Group 2: NLA \\
\hline Outcomes & Assessment of bleeding and pain using CHEOPS \\
& $\begin{array}{l}\text { Measured at "period between the child awakening and being sufficiently recovered to return to the dis- } \\
\text { charge waiting area" }\end{array}$ \\
\hline Notes & $\begin{array}{l}\text { Induction intravenously with propofol or inhalation with nitrous oxide and sevoflurane } \\
\text { Co-interventions: All children were premedicated with oral paracetamol (20 } \mathrm{mg} / \mathrm{kg}) \text { and ibuprofen }(5\end{array}$ \\
& Declarations of interest: none reported \\
& A sample size calculation was carried out during the trial after recruitment of the first $40 \mathrm{children}$
\end{tabular}

Risk of bias

\begin{tabular}{lll}
\hline Bias & Authors' judgement & Support for judgement \\
\hline $\begin{array}{ll}\text { Random sequence genera- } \\
\text { tion (selection bias) }\end{array}$ & Low risk & $\begin{array}{l}\text { Quote: "...randomization list previously prepared by a computer (Arcus Quick- } \\
\text { stat V1.0)" }\end{array}$ \\
& & Comment: Randomisation was computer-generated
\end{tabular}

\begin{tabular}{l}
$\begin{array}{l}\text { Allocation concealment } \\
\text { (selection bias) }\end{array}$ Unclear risk Comment: The paper did not describe the method of allocation concealment \\
\hline
\end{tabular}

\begin{tabular}{|c|c|c|}
\hline $\begin{array}{l}\text { Blinding of participants } \\
\text { and personnel (perfor- } \\
\text { mance bias) } \\
\text { All outcomes }\end{array}$ & Low risk & $\begin{array}{l}\text { Quote: "The dental operator performing the extractions could thus not be } \\
\text { blinded with regard to use of local anaesthetic, since it was she who adminis- } \\
\text { tered it" } \\
\text { Comment: The study blinded participants }\end{array}$ \\
\hline $\begin{array}{l}\text { Blinding of outcome as- } \\
\text { sessment (detection bias) } \\
\text { All outcomes }\end{array}$ & Low risk & $\begin{array}{l}\text { Quote: "Bleeding and pain were assessed by PACU staff who were blinded to } \\
\text { the treatment allocation and not present in theatre at time of randomization" } \\
\text { Comment: The study blinded assessment }\end{array}$ \\
\hline
\end{tabular}

\begin{tabular}{ll}
\hline $\begin{array}{l}\text { Incomplete outcome data } \\
\text { (attrition bias) }\end{array}$ & Low risk \\
All outcomes & $\begin{array}{l}\text { The paper clearly described reasons for incomplete data, which was similar } \\
\text { across groups. 9/85 were given opioid fentanyl IV and for 8, there was failure to } \\
\text { collect all data for CHEOPS }\end{array}$ \\
\hline
\end{tabular}

\begin{tabular}{|c|c|c|}
\hline $\begin{array}{l}\text { Selective reporting (re- } \\
\text { porting bias) }\end{array}$ & Low risk & $\begin{array}{l}\text { The study recorded all expected outcomes; however, we note that there was } \\
\text { an inconsistency in the reporting of the CHEOPS score. In table } 2 \text {, the lower } \\
\text { limit of the range was } 0 \text {, which is technically impossible (the CHEOPS score } \\
\text { ranges from a minimum of } 4 \text { to a maximum of } 13 \text { ). We decided to assume this } \\
\text { was a reporting error }\end{array}$ \\
\hline
\end{tabular}

Other bias Low risk There was no other apparent bias


Noble 1994

\begin{tabular}{|c|c|}
\hline \multirow[t]{6}{*}{ Methods } & Study design: 2-arm parallel randomised trial \\
\hline & Conducted in: UK \\
\hline & Number of centres: 1 \\
\hline & Setting: dental hospital \\
\hline & Recruitment period: unclear \\
\hline & Funding source: not reported \\
\hline \multirow[t]{5}{*}{ Participants } & Inclusion criteria: 3 to 14 years of age having 1 or more teeth extracted \\
\hline & Exclusion criteria: failure to obtain consent and abscess formation \\
\hline & $\begin{array}{l}\text { Number of participants randomised/evaluated: total = } 100 \text { (group } 1=57 \text { ( } 28 \text { male, } 29 \text { female), group } 2= \\
43(27 \text { male, } 16 \text { female)) }\end{array}$ \\
\hline & Group 1: mean age $($ years $)=7.1(\mathrm{SEM}=0.7)$ \\
\hline & Group 2: mean age $($ years $)=6.5(\mathrm{SEM}=0.5)$ \\
\hline \multirow[t]{2}{*}{ Interventions } & Group 1: IFL 3\% prilocaine with $0.03 \mathrm{U} / \mathrm{ml}$ felypressin infiltration \\
\hline & Group 2: NLA \\
\hline \multirow[t]{3}{*}{ Outcomes } & Distress scale \\
\hline & Measured at 5 minutes and 30 minutes \\
\hline & Visual assessment scale (VAS) measured at 30 minutes \\
\hline \multirow[t]{4}{*}{ Notes } & $\begin{array}{l}\text { Induction intravenously with methohexital or inhalation with halothane/nitrous oxide. Maintained with } \\
\text { halothane/nitrous oxide }\end{array}$ \\
\hline & $\begin{array}{l}\text { Co-interventions: Children who remained distressed were offered oral acetaminophen oral suspension } \\
\text { before discharge }\end{array}$ \\
\hline & Declarations of interest: none reported \\
\hline & There was no sample size calculation \\
\hline
\end{tabular}

\section{Risk of bias}

\begin{tabular}{lll}
\hline Bias & Authors' judgement & Support for judgement \\
\hline $\begin{array}{l}\text { Random sequence genera- } \\
\text { tion (selection bias) }\end{array}$ & Low risk & $\begin{array}{l}\text { Quote: "...were allocated randomly, by the toss of a coin..." } \\
\text { Comment: The paper stated the method of sequence generation }\end{array}$ \\
\hline $\begin{array}{l}\text { Allocation concealment } \\
\text { (selection bias) }\end{array}$ & Unclear risk & The paper did not provide information on allocation concealment \\
\hline $\begin{array}{l}\text { Blinding of participants } \\
\text { and personnel (perfor- } \\
\text { mance bias) }\end{array}$ & Low risk & \\
\begin{tabular}{l} 
All outcomes \\
\hline
\end{tabular} & $\begin{array}{l}\text { The study blinded participants. It was unclear whether the study blinded per- } \\
\text { sonnel }\end{array}$ \\
\hline
\end{tabular}


Noble 1994 (Continued)

Blinding of outcome as- Low risk Quote: "Postoperative assessments for each patient were performed by one of sessment (detection bias) two anaesthesiologists who was unaware of the child's treatment group"

All outcomes

Quote: "Global assessment of distress by a blinded observer..."

Comment: The study blinded the assessor

Incomplete outcome data Low risk The outcome evaluation included all participants
(attrition bias)

All outcomes

Selective reporting (re- Low risk The study reported all expected outcomes

porting bias)

\begin{tabular}{|c|c|c|}
\hline Other bias & Unclear risk & $\begin{array}{l}\text { There were more males than females in the no-LA group ( } 27 \text { males versus } 16 \\
\text { females in the no-LA group, } 28 \text { versus } 29 \text { in the GA with LA group) }\end{array}$ \\
\hline
\end{tabular}

females in the no-LA group, 28 versus 29 in the GA with LA group)

\section{Quirke 2005}

\begin{tabular}{|c|c|}
\hline \multirow[t]{6}{*}{ Methods } & Study design: 2-arm parallel randomised trial \\
\hline & Conducted in: UK \\
\hline & Number of centres: 1 \\
\hline & Setting: unclear \\
\hline & Recruitment period: unclear \\
\hline & Funding source: not reported \\
\hline \multirow[t]{4}{*}{ Participants } & Inclusion criteria: dental extractions under GA with no complicating medical history and $>15 \mathrm{~kg}$ \\
\hline & Number of participants randomised/evaluated: total = 48 (group $1=24$, group $2=24$ ) \\
\hline & Group 1: median age (years) $=7$ (range $=4$ to 12$)$ \\
\hline & Group 2: median age (years) $=6$ (range $=4$ to 13$)$ \\
\hline \multirow[t]{2}{*}{ Interventions } & Group 1: bupivacaine $0.25 \%$ with 1:200000 topical (swab) \\
\hline & Group 2: saline \\
\hline \multirow[t]{2}{*}{ Outcomes } & TPPPS \\
\hline & Measured at $5,10,15$, and 30 minutes \\
\hline \multirow[t]{3}{*}{ Notes } & Co-interventions: none \\
\hline & Declarations of interest: none reported \\
\hline & There was no sample size calculation \\
\hline
\end{tabular}

\section{Risk of bias}

\begin{tabular}{lll}
\hline Bias & Authors' judgement & Support for judgement \\
\hline $\begin{array}{l}\text { Random sequence genera- } \\
\text { tion (selection bias) }\end{array}$ & Low risk & Quote: "Treatment was randomised by the use of a book of random numbers" \\
\hline
\end{tabular}


Quirke 2005 (Continued)

Comment: The paper stated the method of sequence generation

\begin{tabular}{ll}
\hline $\begin{array}{l}\text { Allocation concealment } \\
\text { (selection bias) }\end{array}$ & $\begin{array}{l}\text { Quote: "Only the pharmacy department were aware of whether bupivacaine } \\
0.25 \% \ldots \text { or placebo...was being administered" }\end{array}$ \\
& Comment: We assumed allocation concealment was adequate
\end{tabular}

\begin{tabular}{|c|c|c|}
\hline $\begin{array}{l}\text { Blinding of participants } \\
\text { and personnel (perfor- } \\
\text { mance bias) }\end{array}$ & Low risk & $\begin{array}{l}\text { Quote: "...double blind" } \\
\text { Comment: We assumed the study blinded participants and assessors }\end{array}$ \\
\hline
\end{tabular}

Alloutcomes

\begin{tabular}{|c|c|c|}
\hline $\begin{array}{l}\text { Blinding of outcome as- } \\
\text { sessment (detection bias) }\end{array}$ & Low risk & Quote: "...double blind" \\
\hline All outcomes & & Comment: We assumed the study blinded participants and assessors \\
\hline
\end{tabular}

\begin{tabular}{lll}
\hline $\begin{array}{l}\text { Incomplete outcome data } \\
\text { (attrition bias) } \\
\text { All outcomes }\end{array}$ & Low risk & The outcome evaluation included all participants \\
\hline $\begin{array}{l}\text { Selective reporting (re- } \\
\text { porting bias) }\end{array}$ & Low risk & The study reported all expected outcomes \\
\hline Other bias & Low risk & There was no other apparent bias \\
\hline
\end{tabular}

Rashad 1990

\begin{tabular}{|c|c|}
\hline \multirow[t]{6}{*}{ Methods } & Study design: 2-arm parallel randomised trial \\
\hline & Conducted in: Saudi Arabia \\
\hline & Number of centres: 1 \\
\hline & Setting: hospital \\
\hline & Recruitment period: unclear \\
\hline & Funding source: not reported \\
\hline \multirow[t]{4}{*}{ Participants } & Inclusion criteria: ASA grade 1 , oral surgery procedures \\
\hline & $\begin{array}{l}\text { Number of participants randomised/evaluated: total }=100 \text { (group } 1=50 \text { ( } 29 \text { male, } 21 \text { female), group } 2= \\
50 \text { ( } 26 \text { male, } 24 \text { female)) }\end{array}$ \\
\hline & Group 1: mean age $($ years $)=11.4($ SD 8.1, range $=4$ to 37$)$ \\
\hline & Group 2: mean age $($ years $)=12.8($ SD 9.3, range $=5$ to 40$)$ \\
\hline \multirow[t]{2}{*}{ Interventions } & Group 1: IFL saline infiltration or block \\
\hline & Group 2: IFL plain lidocaine $2 \%$ infiltration or block \\
\hline \multirow[t]{2}{*}{ Outcomes } & $\begin{array}{l}\text { First complaint of pain or request for analgesics, cardiac dysthymias using ECG before and throughout } \\
\text { procedure }\end{array}$ \\
\hline & Measured at early postoperative \\
\hline
\end{tabular}


Declarations of interest: none reported

There was no sample size calculation

Halothane/nitrous oxide anaesthesia

Although 100 consecutive participants were recruited, the participant were then allocated to 2 groups randomly

\section{Risk of bias}

\begin{tabular}{|c|c|c|}
\hline Bias & Authors' judgement & Support for judgement \\
\hline $\begin{array}{l}\text { Random sequence genera- } \\
\text { tion (selection bias) }\end{array}$ & Unclear risk & The paper did not describe the method of sequence generation \\
\hline $\begin{array}{l}\text { Allocation concealment } \\
\text { (selection bias) }\end{array}$ & Unclear risk & The paper did not describe the method of allocation concealment \\
\hline $\begin{array}{l}\text { Blinding of participants } \\
\text { and personnel (perfor- } \\
\text { mance bias) } \\
\text { All outcomes }\end{array}$ & Low risk & The paper described the study as being double-blind \\
\hline $\begin{array}{l}\text { Blinding of outcome as- } \\
\text { sessment (detection bias) } \\
\text { All outcomes }\end{array}$ & Low risk & The paper described the study as being double-blind \\
\hline $\begin{array}{l}\text { Incomplete outcome data } \\
\text { (attrition bias) } \\
\text { All outcomes }\end{array}$ & Low risk & The study included all participants \\
\hline $\begin{array}{l}\text { Selective reporting (re- } \\
\text { porting bias) }\end{array}$ & Low risk & The study reported all planned outcomes \\
\hline Other bias & Low risk & There was no other apparent bias \\
\hline
\end{tabular}

\section{Sammons 2007}

Study design: 2-arm parallel randomised trial
Conducted in: UK
Number of centres: 1
Setting: hospital
Recruitment period: unclear
Funding source: new investigator Award. Southern Derbyshire Acute Hospitals NHS Trust

\section{Participants} Inclusion criteria: fit and well, able to understand pain scale, parent understands English

Exclusion criteria: porphyria, cardiac disorders, liver or renal impairment

Number of participants randomised: total $=86$ (group $1=42$, group $2=44$ ) 
Sammons 2007 (Continued)

Number of participants evaluated: total $=85$ (group $1=41$, group $2=44)$

47 male, 38 female (equal distribution in groups)

Age range $=24$ to 60 months

\begin{tabular}{ll}
\hline Interventions & Group 1: ITR $2 \%$ lignocaine with 1:80000 adrenaline, dose 0.15 to $2 \mathrm{ml}$ intraligamental \\
& Group 2: NLA \\
\hline Outcomes & TPPPS, Wong-Baker FACES ${ }^{\circledR}$ Pain Rating Scale \\
& Measured at 5, 15, 30, and 60 minutes \\
\hline Notes & Co-interventions: All participants received ibuprofen $(10 \mathrm{mg} / \mathrm{kg})$ and paracetamol (20 $\mathrm{mg} / \mathrm{kg})$. If further \\
analgesia was required postoperatively, $500 \mathrm{Ug} 1 \mathrm{mg} / \mathrm{kg}$ was given \\
Declarations of interest: none reported \\
There was a sample size calculation \\
All children \\
The study terminated early for no reason given by the primary care trust; the sample size was not \\
achieved (116 required, 85 analysed)
\end{tabular}

\section{Risk of bias}

\begin{tabular}{|c|c|c|}
\hline Bias & Authors' judgement & Support for judgement \\
\hline $\begin{array}{l}\text { Random sequence genera- } \\
\text { tion (selection bias) }\end{array}$ & Low risk & $\begin{array}{l}\text { Quote: "...were randomized" "Block randomization was done by the statisti- } \\
\text { cian" } \\
\text { Comment: The paper stated the method of sequence generation }\end{array}$ \\
\hline $\begin{array}{l}\text { Allocation concealment } \\
\text { (selection bias) }\end{array}$ & Low risk & $\begin{array}{l}\text { Quote: "Randomization was placed into sealed envelopes" } \\
\text { Comment: The study used 'sealed envelopes', but there was no indication of } \\
\text { whether these were sequentially numbered or opaque }\end{array}$ \\
\hline $\begin{array}{l}\text { Blinding of participants } \\
\text { and personnel (perfor- } \\
\text { mance bias) } \\
\text { All outcomes }\end{array}$ & Low risk & $\begin{array}{l}\text { Quote: "...single blinded" } \\
\text { Comment: The study blinded participants } \\
\text { The study did not blind the personnel performing the extractions }\end{array}$ \\
\hline $\begin{array}{l}\text { Blinding of outcome as- } \\
\text { sessment (detection bias) } \\
\text { All outcomes }\end{array}$ & Low risk & $\begin{array}{l}\text { Quote: "Pain assessments were performed by one of the two investigators } \\
\text { blinded to the child's treatment" } \\
\text { Comment: The study blinded the assessor to participant treatment }\end{array}$ \\
\hline $\begin{array}{l}\text { Incomplete outcome data } \\
\text { (attrition bias) } \\
\text { All outcomes }\end{array}$ & Low risk & $\begin{array}{l}\text { Quote: "One child in the lignocaine group did not stay for the whole hour post- } \\
\text { operatively and was excluded from the analysis" } \\
\text { Comment: There was minimal dropout for the primary outcome }\end{array}$ \\
\hline $\begin{array}{l}\text { Selective reporting (re- } \\
\text { porting bias) }\end{array}$ & Low risk & The study reported all expected outcomes \\
\hline Other bias & Low risk & There was no other apparent bias \\
\hline
\end{tabular}


Townsend 2009

Methods
Study design: 2-arm parallel randomised trial
Conducted in: USA
Number of centres: 1
Setting: dental surgery centre, children's hospital
Recruitment period: unclear
Funding source: not reported

Participants

Inclusion criteria: ASA I to II, speak English, free of developmental delay or psychiatric conditions, minimum of 2 fillings, 2 anterior extraction, and placement of 4 preformed crown with 1 in each arch

Exclusion criteria: adverse drug reaction or medical contraindication

Number of participants randomised/evaluated: total $=27$ (group $1=15$ ( 5 female, 10 male), group $2=$ 12 (3 female, 9 male))

Group 1 mean age $($ years $)=4.3(S D=0.78)$

Group 2 mean age (years) $=3.8(S D=0.68)$

Age range $=3$ to 5.5 years

\begin{tabular}{|c|c|}
\hline \multirow[t]{2}{*}{ Interventions } & $\begin{array}{l}\text { Group 1: IFL } 1 \mathrm{mg} / \mathrm{kg} \text { ketorolac and } 0.3 \mathrm{ml} 2 \% \text { lidocaine with 1:100000 adrenaline infiltration of each } \\
\text { tooth treated }\end{array}$ \\
\hline & Group 2: $1 \mathrm{mg} / \mathrm{kg}$ ketorolac \\
\hline \multirow[t]{2}{*}{ Outcomes } & FLACC Pain Assessment Tool and Wong-Baker FACES ${ }^{\circledR}$ Pain Rating Scale \\
\hline & Measured at 5 minutes and 4 to 6 hours \\
\hline \multirow[t]{4}{*}{ Notes } & Induction sevoflurane, propofol, or both, maintained with isoflurane/nitrous oxide \\
\hline & $\begin{array}{l}\text { Co-interventions: All participants received dexamethasone } 0.1 \mathrm{mg} / \mathrm{kg} \text { and were given a bottle of parac- } \\
\text { etamol } 15 \mathrm{mg} / \mathrm{kg} \text { at discharge }\end{array}$ \\
\hline & Declarations of interest: none reported \\
\hline & There was no sample size calculation \\
\hline
\end{tabular}

\section{Risk of bias}

\begin{tabular}{lll}
\hline Bias & Authors' judgement & Support for judgement \\
\hline $\begin{array}{l}\text { Random sequence genera- } \\
\text { tion (selection bias) }\end{array}$ & Low risk & $\begin{array}{l}\text { Quote: "...assigned by a random number generator" } \\
\text { Comment: We assumed the sequence generation was computer-generated }\end{array}$ \\
\hline $\begin{array}{l}\text { Allocation concealment } \\
\text { (selection bias) }\end{array}$ & Unclear risk & There was insufficient information to make a judgement \\
\hline $\begin{array}{l}\text { Blinding of participants } \\
\text { and personnel (perfor- } \\
\text { mance bias) } \\
\text { All outcomes }\end{array}$ & Low risk & $\begin{array}{l}\text { Quote: "The surgeon and anaesthesiologist were not blinded to local anaes- } \\
\text { thetic administration" }\end{array}$ \\
\hline
\end{tabular}


Townsend 2009 (Continued)

Blinding of outcome as- Low risk Quote: "The nurse, who was blinded to local anesthetic status, evaluated the sessment (detection bias)

All outcomes patient at 5-minute intervals"

"Parents were also blinded as to local anesthetic administration"

Comment: The study blinded the assessor

\begin{tabular}{lll}
\hline $\begin{array}{l}\text { Incomplete outcome data } \\
\text { (attrition bias) } \\
\text { All outcomes }\end{array}$ & Low risk & $\begin{array}{l}\text { All participants were accounted for at follow up prior to discharge; outcome } \\
\text { measures for 20/27 children at follow up at home; loss to follow up was similar } \\
\text { across groups }\end{array}$ \\
\hline $\begin{array}{l}\text { Selective reporting (re- } \\
\text { porting bias) }\end{array}$ & Low risk & The study recorded all expected outcomes \\
\hline Other bias & Low risk & There was no other apparent bias \\
\hline
\end{tabular}

Watts 2009

\begin{tabular}{|c|c|}
\hline \multirow[t]{6}{*}{ Methods } & Study design: 2-arm parallel randomised trial \\
\hline & Conducted in: USA \\
\hline & Number of centres: 1 \\
\hline & Setting: hospital \\
\hline & Recruitment period: unclear \\
\hline & Funding source: not reported \\
\hline \multirow[t]{5}{*}{ Participants } & $\begin{array}{l}\text { Inclusion criteria: } 12 \text { to } 84 \text { months, at least } 1 \text { extraction of a primary maxillary tooth, use of a clamp, } \\
\text { and at least } 1 \text { maxillary tooth needing pulpotomy/crown }\end{array}$ \\
\hline & Number of participants randomised/evaluated: total = 48 (group $1=24$, group $2=24$ ) \\
\hline & Group 1: mean age (years) = 3.71 \\
\hline & Group 2: mean age (years) $=4.03$ \\
\hline & 25 males, 23 females \\
\hline \multirow[t]{2}{*}{ Interventions } & Group 1: IFL 2\% xylocaine with 1:100000 adrenaline \\
\hline & Group 2: no LA \\
\hline Outcomes & Heart rate, respiratory rate, end tidal carbon dioxide \\
\hline \multirow[t]{5}{*}{ Notes } & Induction sevoflurane, maintained with isoflurane/nitrous oxide \\
\hline & Co-interventions: All participants received $1 \mathrm{mg} / \mathrm{kg}$ of Keterolac 30 minutes before end of case \\
\hline & Declarations of interest: none reported \\
\hline & There was a sample size calculation \\
\hline & Results were reported separately for different dental procedures \\
\hline
\end{tabular}

\section{Risk of bias}

Intraoperative local anaesthesia for reduction of postoperative pain following general anaesthesia for dental treatment in children and 
Watts 2009 (Continued)

\begin{tabular}{|c|c|c|}
\hline Bias & Authors' judgement & Support for judgement \\
\hline \multirow{2}{*}{$\begin{array}{l}\text { Random sequence genera- } \\
\text { tion (selection bias) }\end{array}$} & Unclear risk & Quote: "...randomly assigned" \\
\hline & & Comment: The paper did not state the method of sequence generation \\
\hline $\begin{array}{l}\text { Allocation concealment } \\
\text { (selection bias) }\end{array}$ & Unclear risk & There was insufficient information to make a judgement \\
\hline \multirow{3}{*}{$\begin{array}{l}\text { Blinding of participants } \\
\text { and personnel (perfor- } \\
\text { mance bias) } \\
\text { All outcomes }\end{array}$} & Low risk & Quote: "The operators, anaesthesiologists and recorders were not blinded" \\
\hline & & Comment: The study blinded participants. Outcome assessment was consid- \\
\hline & & $\begin{array}{l}\text { ered to be "objective"; therefore; the study authors justified the lack of blind- } \\
\text { ing of personnel }\end{array}$ \\
\hline \multirow{2}{*}{$\begin{array}{l}\text { Blinding of outcome as- } \\
\text { sessment (detection bias) } \\
\text { All outcomes }\end{array}$} & High risk & Quote: "The operators, anaesthesiologists and recorders were not blinded" \\
\hline & & $\begin{array}{l}\text { Comment: Outcome assessment was considered to be "objective"; therefore, } \\
\text { the study authors justified the lack of blinding of outcome assessment }\end{array}$ \\
\hline $\begin{array}{l}\text { Incomplete outcome data } \\
\text { (attrition bias) }\end{array}$ & High risk & $\begin{array}{l}\text { All participants were included in the analysis, but the study authors reported } \\
\text { that "only } 46 \text { percent of the study data being complete collections per patient" }\end{array}$ \\
\hline
\end{tabular}

Selective reporting (re- Low risk The study recorded all expected outcomes
porting bias)

Other bias Low risk There was no other apparent bias.

ASA = American Society of Anesthesiology Classification; ASA I = normal, healthy patient; ASA II = patient with mild systemic disease / no functional limitation; CHEOPS = Children's Hospital of Eastern Ontario Pain Scale; ECG = electrocardiogram; EMLA = eutectic mixture of local anaesthetics; FLACC = Faces Legs Activity Crying Consolability; GA = general anaesthesia; IFL = immediate functional loading; ILA = intraoperative local anaesthesia; ITR = intraligamental injection; IV = intravenous; LA = local anaesthetic; MPDS = modified pain/discomfort scale; NLA = no local anaesthesia; PACU = post-anesthesia care unit; SD = standard deviation; SEM = standard error of the mean; STPPPS = Simplified Toddler Preschooler-Postoperative Pain Scale; TPPPS = Toddler Preschooler-Postoperative Pain Scale; VAS = visual analogue scale.

Characteristics of excluded studies [ordered by study ID]

\begin{tabular}{ll}
\hline Study & Reason for exclusion \\
\hline Bhananker 2008 & This used a positive control containing morphine \\
\hline Greengrass 1998 & LA was placed after the operation finished and the participant was awake \\
\hline Jürgens 2003 & This was not an RCT \\
\hline Ogg 1983 & This did not use local anaesthetic \\
\hline
\end{tabular}

$\mathrm{LA}=$ local anaesthetic; $\mathrm{RCT}=$ randomised controlled trial.

\section{ADDITIONAL TABLES}


Table 1. Local anaesthetic used

\begin{tabular}{ll}
\hline Local anaesthetic & Study \\
\hline $2 \%$ lignocaine with 1:80000 adrenaline & $\begin{array}{c}\text { Al-Bahlani 2001; Leong 2007; Sammons } \\
2007\end{array}$ \\
\hline $2 \%$ lignocaine with 1:200000 adrenaline & Coulthard 2006 \\
\hline $2 \%$ lignocaine with 1:100000 adrenaline & Townsend 2009; Watts 2009 \\
\hline $2 \%$ lignocaine & Rashad 1990 \\
\hline $4 \%$ lignocaine with 1:80000 adrenaline & McWilliams 2007 \\
\hline $0.5 \%$ bupivacaine with 1:200000 adrenaline & Anand 2005 \\
\hline $3 \%$ prilocaine 0.03 U/ml felypressin & Noble 1994 \\
\hline 4 mg/kg lignocaine (delivered as spray) & Elhakim 1993 \\
\hline $0.25 \%$ bupivacaine (topical) with 1:4000 adrenaline & Gazal 2004 \\
\hline $0.25 \%$ bupivacaine (topical) with 1:200000 adrenaline & Andrzejowski 2002; Quirke 2005 \\
\hline
\end{tabular}

Table 2. Pain/distress scales

\begin{tabular}{|c|c|c|c|}
\hline Pain/distress scale & Description & Recorded by & Study \\
\hline 5-face scale of distress & $\begin{array}{l}\text { 5-face scale ranging from no distress to very severe } \\
\text { distress }\end{array}$ & Self-reported & Gazal 2004 \\
\hline 4-category scale of distress & 4-point scale ranging from happy to distressed & Investigator & Noble 1994 \\
\hline 5-category scale of distress & 5-point scale ranging from asleep to distressed & Investigator & Coulthard 2006 \\
\hline $\begin{array}{l}\text { Faces Legs Activity Crying } \\
\text { Consolability (FLACC) assess- } \\
\text { ment tool }\end{array}$ & $\begin{array}{l}\text { Aggregate score based on observation of facial ex- } \\
\text { pression, leg movement, activity, crying, and consola- } \\
\text { bility }\end{array}$ & Investigator & Townsend 2009 \\
\hline $\begin{array}{l}\text { Modified pain/discomfort } \\
\text { scale (MPDS) }\end{array}$ & $\begin{array}{l}\text { Aggregate score based on observation of crying, } \\
\text { movement, and agitation }\end{array}$ & Investigator & Leong 2007 \\
\hline $\begin{array}{l}\text { Children's Hospital of East- } \\
\text { ern Ontario Pain Scale } \\
\text { (CHEOPS) }\end{array}$ & $\begin{array}{l}\text { Aggregate score based on observation of crying, facial } \\
\text { expression, verbal expression pain, torso movement, } \\
\text { child touching the "wound", and leg movement }\end{array}$ & Investigator & McWilliams 2007 \\
\hline Presence/absence of pain & - & $\begin{array}{l}\text { Investigator/self-re- } \\
\text { ported }\end{array}$ & $\begin{array}{l}\text { Elhakim 1993; } \\
\text { Rashad } 1990\end{array}$ \\
\hline $\begin{array}{l}\text { Simplified Toddler } \\
\text { Preschooler-Postoperative } \\
\text { pain scale (STPPPS) or Tod- } \\
\text { dler Preschooler-Postopera- } \\
\text { tive pain scale system (TPP- } \\
\text { PS) }\end{array}$ & $\begin{array}{l}\text { Aggregate score based on observation of vocal pain } \\
\text { expression, facial pain expression, and body pain ex- } \\
\text { pression }\end{array}$ & Investigator & $\begin{array}{l}\text { Al-Bahlani 2001; } \\
\text { Leong 2007; Quirke } \\
\text { 2005; Sammons } \\
2007\end{array}$ \\
\hline
\end{tabular}


Table 2. Pain/distress scales (Continued)

\begin{tabular}{llll} 
Visual analogue scale (VAS) & $\begin{array}{l}\text { Self-reporting of pain based on a line ranging from no } \\
\text { pain to worst pain }\end{array}$ & Self-reported & $\begin{array}{l}\text { Anand 2005; Noble } \\
1994\end{array}$ \\
\hline $\begin{array}{l}\text { Wong-Baker FACES } \\
\text { ing Scale }\end{array}$ & $\begin{array}{l}\text { 6-face scale for pain intensity assessment ranging } \\
\text { from no hurt to hurts worst }\end{array}$ & $\begin{array}{l}\text { Self-reported/Par- } \\
\text { entp-reported }\end{array}$ & $\begin{array}{l}\text { Sammons 2007; } \\
\text { Townsend 2009 }\end{array}$ \\
\hline 5-face pain scale & $\begin{array}{l}\text { 5-face scale for pain intensity assessment ranging } \\
\text { from no pain to very severe pain }\end{array}$ & Self-reported & Coulthard 2006 \\
\hline 4-face pain scale & $\begin{array}{l}\text { 4-face scale for pain intensity assessment ranging } \\
\text { from 'I don't hurt at all' to 'I hurt the most' }\end{array}$ & Self-reported & Andrzejowski 2002
\end{tabular}

CHEOPS $=$ Children's Hospital of Eastern Ontario Pain Scale.FLACC $=$ Faces Legs Activity Crying Consolability.

MPDS = modified pain/discomfort scale.

STPPPS = Simplified Toddler Preschooler-Postoperative Pain Scale.

TPPPS = Toddler Preschooler-Postoperative Pain Scale.

VAS = visual assessment scale.

Table 3. Infiltration injection LA versus placebo or no treatment (7 studies)

\section{Lignocaine plus adrenaline}

\begin{tabular}{|c|c|c|c|c|}
\hline Study & Outcome & Treatment & Comparator & Results \\
\hline & & LA & Saline placebo & \\
\hline \multirow[t]{6}{*}{$\begin{array}{l}\text { Coulthard } \\
2006^{\star+}\end{array}$} & Pain (5-face scale) waking & $\begin{array}{l}\text { Mean } 1.45(1.38 \\
\text { sd) } N=70\end{array}$ & $\begin{array}{l}\text { Mean } 1.37(1.32 \mathrm{sd}) \\
\mathrm{N}=69\end{array}$ & $\begin{array}{l}0.08 \text { (95\% } \mathrm{Cl}-0.37 \text { to } 0.53) \mathrm{P}= \\
0.72 \text { (t-test) }\end{array}$ \\
\hline & $\begin{array}{l}\text { Pain (5-face scale) } 30 \text { minutes } \\
\text { postoperatively }\end{array}$ & $\begin{array}{l}\text { Mean } 1.74(1.44 \\
\text { sd) } N=70\end{array}$ & $\begin{array}{l}\text { Mean } 1.70(1.32 \mathrm{sd}) \\
\mathrm{N}=69\end{array}$ & $\begin{array}{l}0.04(95 \% \mathrm{Cl}-0.42 \text { to } 0.50) \mathrm{P}= \\
0.86 \text { (t-test) }\end{array}$ \\
\hline & $\begin{array}{l}\text { Pain (5-face scale) } 24 \text { hours post- } \\
\text { operatively }\end{array}$ & $\begin{array}{l}\text { Mean } 0.69(1.10 \\
\text { sd) } N=70\end{array}$ & $\begin{array}{l}\text { Mean } 0.75(1.23 \mathrm{sd}) \\
\mathrm{N}=69\end{array}$ & $\begin{array}{l}-0.06(95 \% \mathrm{Cl}-0.45 \text { to } 0.33) \mathrm{P}= \\
0.76 \text { (t-test) }\end{array}$ \\
\hline & Distress (5-category) on waking & $\begin{array}{l}\text { Mean } 2.24(0.87 \\
\text { sd) } \mathrm{N}=70\end{array}$ & $\begin{array}{l}\text { Mean } 2.20(0.85 \mathrm{sd}) \\
N=69\end{array}$ & $\begin{array}{l}0.04(95 \% \mathrm{Cl}-0.25 \text { to } 0.33) \mathrm{P}= \\
0.78 \text { (t-test) }\end{array}$ \\
\hline & $\begin{array}{l}\text { Distress (5-category) } 30 \text { minutes } \\
\text { postoperatively }\end{array}$ & $\begin{array}{l}\text { Mean } 2.57(0.83 \\
\text { sd) } N=70\end{array}$ & $\begin{array}{l}\text { Mean } 2.42(0.74 \mathrm{sd}) \\
\mathrm{N}=69\end{array}$ & $\begin{array}{l}0.15 \text { (95\% } \mathrm{Cl}-0.11 \text { to } 0.41) \mathrm{P}= \\
0.26 \text { (t-test) }\end{array}$ \\
\hline & $\begin{array}{l}\text { Lip or cheek biting } 24 \text { hours post- } \\
\text { operatively }\end{array}$ & $3 / 70$ & $1 / 69$ & $P=0.62$ (Fisher's exact test) \\
\hline \multirow[t]{2}{*}{ Study } & Outcome & Treatment & Comparator & Results \\
\hline & & LA & No treatment & \\
\hline \multirow[t]{2}{*}{ Watts $2009^{\star+}$} & Heart rate & $\begin{array}{l}\text { Mean } 119.53 \mathrm{bpm} \\
(16.50 \mathrm{sd}) \text { for LA. } \mathrm{n} \\
=24\end{array}$ & $\begin{array}{l}\text { Mean } 124.38 \text { bpm } \\
(16.45 \mathrm{sd}) \mathrm{n}=24\end{array}$ & $\begin{array}{l}-4.85(95 \% \mathrm{Cl}-14.42 \text { to } 4.72) \mathrm{P} \\
=0.31 \text { (t-test) }\end{array}$ \\
\hline & End tidal $\mathrm{CO} 2$ & $\begin{array}{l}\text { Mean } 50.2 \mathrm{~mm} \mathrm{Hg} \\
(3.55 \mathrm{sd}) \mathrm{n}=24\end{array}$ & $\begin{array}{l}\text { Mean } 47.46 \mathrm{~mm} \mathrm{Hg} \\
(4.16 \mathrm{sd}) \mathrm{n}=24\end{array}$ & $\begin{array}{l}2.74(95 \% \mathrm{Cl} 0.49 \text { to } 4.99) \mathrm{P}= \\
0.02 \text { (t-test) }\end{array}$ \\
\hline
\end{tabular}


Table 3. Infiltration injection LA versus placebo or no treatment (7 studies) (Continued)

\begin{tabular}{|c|c|c|c|c|}
\hline & Respiratory rate & $\begin{array}{l}\text { Mean } 30.33 \text { brpm } \\
(5.08 \mathrm{sd}) \mathrm{n}=24\end{array}$ & $\begin{array}{l}\text { Mean } 32.08 \text { brpm } \\
(5.50 \mathrm{sd}) \mathrm{n}=24\end{array}$ & $\begin{array}{l}-1.75(95 \% \mathrm{Cl}-4.83 \text { to } 1.33) \mathrm{P}= \\
0.26 \text { (t-test) }\end{array}$ \\
\hline \multirow[t]{4}{*}{ Townsend 2009+ } & $\begin{array}{l}\text { Pain (Wong-Baker FACES }{ }^{\circledR} \text { Pain } \\
\text { Rating Scale, } 6 \text {-face scale) imme- } \\
\text { diately postoperatively }\end{array}$ & $N=15$ & $N=12$ & $\begin{array}{l}\text { Results not reported; au- } \\
\text { thors 'did not use Wong-Baker } \\
\text { FACES immediately post-oper- } \\
\text { atively due to variable cooper- } \\
\text { ation of subjects' }\end{array}$ \\
\hline & $\begin{array}{l}\text { Pain (Wong-Baker FACES }{ }^{\circledR} \text { Pain } \\
\text { Rating Scale, } 6 \text {-face scale) } \\
\text { evening following surgery }\end{array}$ & $\begin{array}{l}\text { Mean } 0.30(0.21) n \\
=10\end{array}$ & $\begin{array}{l}\text { Mean } 0.60(1.35) n= \\
10\end{array}$ & $\begin{array}{l}P=0.92 \text { (Wilcoxon Rank Sum } \\
\text { test) }\end{array}$ \\
\hline & $\begin{array}{l}\text { Distress (FLACC) closest to dis- } \\
\text { charge }\end{array}$ & $\begin{array}{l}\text { Mean } 2.47(2.69) n \\
=15\end{array}$ & $\begin{array}{l}\text { Mean } 2.58(2.54) n= \\
12\end{array}$ & $\begin{array}{l}\mathrm{P}=0.88 \text { (Wilcoxon Rank Sum } \\
\text { test) }\end{array}$ \\
\hline & $\begin{array}{l}\text { Lip or cheek biting evening fol- } \\
\text { lowing surgery* }\end{array}$ & $4 / 11$ & $1 / 12$ & $P=0.16$ (Fisher's exact test) \\
\hline \multirow[t]{2}{*}{$\begin{array}{l}\text { McWilliams } \\
2007^{+}\end{array}$} & $\begin{array}{l}\text { Pain (CHEOPS range } 4 \text { to } 13 \text { ) As- } \\
\text { sessment at 'period between } \\
\text { when they awoke and when they } \\
\text { were sufficiently recovered to } \\
\text { leave for the discharge waiting } \\
\text { area'. Exact time not specified }\end{array}$ & $\begin{array}{l}\text { Median } 6 \text { (IQR } 5 \text { to } \\
\text { 8) } N=38\end{array}$ & $\begin{array}{l}\text { Median } 6 \text { (IQR } 5 \text { to } \\
8.75) n=38\end{array}$ & $P=0.99$ (Mann Whitney $U$ test $)$ \\
\hline & $\begin{array}{l}\text { Bleeding (suctioning for bleed- } \\
\text { ing)* }\end{array}$ & $0 / 38$ & $5 / 38$ & $P=0.05$ (Fisher's exact test) \\
\hline \multirow[t]{2}{*}{ Al-Bahlani 2001} & $\begin{array}{l}\text { Pain (TPPPS) 11-minute period of } \\
\text { observation }\end{array}$ & $\begin{array}{l}\text { Mean rank } 63.96 \mathrm{n} \\
=50\end{array}$ & $\begin{array}{l}\text { Mean rank } 37.07 n= \\
50\end{array}$ & $\begin{array}{l}\mathrm{P}<0.0001 \text { (Mann Whitney } \mathrm{U} \\
\text { Test) }\end{array}$ \\
\hline & $\begin{array}{l}\text { Bleeding (collection of 'all the as- } \\
\text { pirated fluids and used swabs')* }\end{array}$ & $\begin{array}{l}\text { Mean total blood } \\
\text { loss per root } 0.79 \\
(\text { sd } 0.06) n=48\end{array}$ & $\begin{array}{l}\text { Mean total blood } \\
\text { loss per root } 1.19 \\
(\text { sd } 0.1) n=50\end{array}$ & $\begin{array}{l}-0.4(95 \% \mathrm{Cl}-0.43 \text { to }-0.37) \mathrm{P}< \\
0.0001(\mathrm{t}-\mathrm{test})(2 \text { outlying val- } \\
\text { ues removed } 6.16 \text { and } 3.96)\end{array}$ \\
\hline
\end{tabular}

\section{Lignocaine alone}

\begin{tabular}{|c|c|c|c|c|}
\hline Study & Outcome & Treatment & Comparator & Results \\
\hline & & LA & Placebo & \\
\hline \multirow[t]{5}{*}{ Rashad 1990*+ } & $\begin{array}{l}\text { Postoperative pain (presence or } \\
\text { absence) }\end{array}$ & $21 / 50$ & $36 / 50$ & $P=0.004$ (Fisher's exact test) \\
\hline & $\begin{array}{l}\text { Maximum pulse rate during } \\
\text { surgery }\end{array}$ & $\begin{array}{l}\text { Mean } 83.3(9.6 \mathrm{sd}) \\
\mathrm{n}=50\end{array}$ & $\begin{array}{l}\text { Mean } 99.6(14.1 \mathrm{sd}) \\
\mathrm{n}=50\end{array}$ & $\begin{array}{l}-16.3(95 \% \mathrm{Cl}-21.09 \text { to }-11.51) \\
\mathrm{P}<0.001 \text { (t-test) }\end{array}$ \\
\hline & End tidal $\mathrm{CO} 2$ postoperative & $\begin{array}{l}\text { Mean } 39.8 \mathrm{nn} \mathrm{Hg} \\
(3.8) \mathrm{n}=50\end{array}$ & $\begin{array}{l}\text { Mean } 38.8 \mathrm{mmHg} \\
(4.2 \mathrm{sd}) \mathrm{n}=50\end{array}$ & $\begin{array}{l}1.0(95 \% \mathrm{Cl}-0.59 \text { to } 2.59) \mathrm{P}= \\
0.21\end{array}$ \\
\hline & $\begin{array}{l}\text { Volume of GA (halothane) deliv- } \\
\text { ered }\end{array}$ & $\begin{array}{l}\text { Mean } 0.86 \%(0.28 \\
\text { sd) } n=50\end{array}$ & $\begin{array}{l}\text { Mean } 1.73 \%(0.03 \\
\text { sd) } n=50\end{array}$ & $\begin{array}{l}-0.87(95 \% \mathrm{Cl}-0.95 \text { to }-0.79) \mathrm{P}< \\
0.001 \text { (t-test) }\end{array}$ \\
\hline & $\begin{array}{l}\text { Incidence of perioperative car- } \\
\text { diac dysrhythmias }\end{array}$ & $1 / 50$ & $14 / 50$ & $\mathrm{P}<0.001$ (Fisher's exact test) \\
\hline
\end{tabular}


Table 3. Infiltration injection LA versus placebo or no treatment (7 studies) (Continued)

Prilocaine plus felypressin

\begin{tabular}{lllll}
\hline Study & Outcome & Treatment & Comparator & Results \\
\hline Noble 1994* & LA & No treatment & \\
& $\begin{array}{l}\text { Distress (4-point scale: high score } \\
\text { high distress) on wakening }\end{array}$ & $\begin{array}{l}\text { Median 2 (1 to 2 } \\
\text { IQR) } n=57\end{array}$ & $\begin{array}{l}\text { Median 3 (2 to 4 } \\
\text { IQR) } n=43\end{array}$ & $\begin{array}{l}\mathrm{P}=0.007 \text { (Mann Whitney U } \\
\text { test) }\end{array}$ \\
\cline { 2 - 5 } & $\begin{array}{llll}\text { Distress (4-point scale: high score } \\
\text { = high distress) before discharge }\end{array}$ & $\begin{array}{l}\text { Median 2 (1 to 3 } \\
\text { IQR) } n=57\end{array}$ & $\begin{array}{l}\text { Median 2 (2 to 3 } \\
\text { IQR) } n=43\end{array}$ & $\mathrm{P}=0.03$ (Mann Whitney U test) \\
\cline { 2 - 5 } & Pain (VAS) & $\begin{array}{l}\mathrm{N}=30 \text { complet- } \\
\text { ed VAS (57 ran- } \\
\text { domised) }\end{array}$ & $\begin{array}{l}\mathrm{N}=23 \text { complet- } \\
\text { ed VAS (43 ran- } \\
\text { domised) }\end{array}$ & $\begin{array}{l}\text { Authors reported 'distressed } \\
\text { children were significantly less } \\
\text { likely to complete this method } \\
\text { of assessment' }\end{array}$ \\
\hline
\end{tabular}

CHEOPS $=$ Children's Hospital of Eastern Ontario Pain Scale.

$\mathrm{Cl}=$ confidence interval.

$\mathrm{CO} 2$ = carbon dioxide.

FLACC $=$ Faces Legs Activity Crying Consolability.

$\mathrm{GA}=$ general anaesthesia.

$\mathrm{IQR}=$ interquartile range

$\mathrm{LA}=$ local anaesthetic.

$\mathrm{n}=$ number.

$\mathrm{P}=\mathrm{P}$ value.

${ }^{\star}$ re-analysis of reported data.

$\mathrm{SD}=$ standard deviation.

+studies where supplementary analgesics were given.

TPPPS $=$ Toddler Preschooler-Postoperative Pain Scale.

VAS = visual assessment scale.

Table 4. Intraligamental injection LA versus no treatment (2 studies)

\section{Bupivacaine plus adrenaline}

\begin{tabular}{|c|c|c|c|c|}
\hline Study & Outcome & Treatment & Comparator & Results \\
\hline & & LA & No treatment & \\
\hline \multirow[t]{4}{*}{ Anand $2005^{+}$} & $\begin{array}{l}\text { Pain (VAS } 0 \text { to } 100 \mathrm{~mm} \text { ) } \\
\text { maxilla on regaining con- } \\
\text { sciousness }\end{array}$ & $\begin{array}{l}\text { Median } 18 \text { ( } 10 \text { to } \\
39 \mathrm{IQR}) \mathrm{n}=29\end{array}$ & $\begin{array}{l}\text { Median } 29 \text { (11 to } \\
50 \mathrm{IQR}) \mathrm{n}=29\end{array}$ & $\begin{array}{l}P=0.33 \text { between test and control sides } \\
P=0.33 \text { (Wilcoxon matched pairs signed } \\
\text { rank) }\end{array}$ \\
\hline & $\begin{array}{l}\text { Pain (VAS } 0 \text { to } 100 \mathrm{~mm} \text { ) } \\
\text { mandible on regaining } \\
\text { consciousness }\end{array}$ & $\begin{array}{l}\text { Median } 20 \text { ( } 5 \text { to } \\
45 \text { IQR) } n=25\end{array}$ & $\begin{array}{l}\text { Median } 30 \text { (12 to } \\
50 I Q R) n=25\end{array}$ & $\begin{array}{l}P=0.29 \text { between test and control sides } \\
P=0.29 \text { (Wilcoxon matched pairs signed } \\
\text { rank) }\end{array}$ \\
\hline & Lip biting, numbness & - & - & $\begin{array}{l}\text { "None of the patients showed signs of } \\
\text { post-operative soft tissue trauma follow- } \\
\text { ing ILA." } 21 \text { children reported numbness } \\
\text { felt on experimental side. Numbness on } \\
\text { no-treatment side was not reported }\end{array}$ \\
\hline & $\begin{array}{l}\text { Postoperative anxiety } \\
\text { (Venham Picture Scale) }\end{array}$ & - & - & $\begin{array}{l}\text { Not appropriate outcome in split mouth } \\
\text { study }\end{array}$ \\
\hline
\end{tabular}


Table 4. Intraligamental injection LA versus no treatment ( 2 studies) (Continued)

Lignocaine plus adrenaline

\begin{tabular}{|c|c|c|c|c|}
\hline Study & Outcome & Treatment & Comparator & Results \\
\hline & & $\mathbf{L A}$ & No treatment & \\
\hline \multirow[t]{3}{*}{ Sammons $2007^{+}$} & $\begin{array}{l}\text { Pain (TPPS } 0 \text { to } 7 \text { ): total } \\
\text { pain score over } 4 \text { time } \\
\text { points in the first hour af- } \\
\text { ter tooth extraction }\end{array}$ & $\begin{array}{l}\text { Median } 3 \text { (0 to } \\
7.5 \mathrm{IQR} \text { ) } \mathrm{n}=41\end{array}$ & $\begin{array}{l}\text { Median } 3 \text { ( } 0 \text { to } 10 \\
\text { IQR) } n=44\end{array}$ & $P=0.42$ (Mann Whitney U Test) \\
\hline & $\begin{array}{l}\text { Pain (Wong-Baker FACES } \\
\text { Pain Rating Scale) }\end{array}$ & $\begin{array}{l}\text { Summary statis- } \\
\text { tics not reported }\end{array}$ & $\begin{array}{l}\text { Summary statis- } \\
\text { tics not reported }\end{array}$ & $\begin{array}{l}\text { "There was no difference in the...pain } \\
\text { scores in the first } 4 \mathrm{~h} \text { after returning home } \\
\text { or on the } 2 \text { days following the extraction." } \\
\mathrm{n}=58\end{array}$ \\
\hline & $\begin{array}{l}\text { Lip or cheek biting, numb- } \\
\text { ness, allergy }\end{array}$ & - & - & $\begin{array}{l}\text { "There were no adverse events reported } \\
\text { in this study" }\end{array}$ \\
\hline
\end{tabular}

$\mathrm{Cl}=$ confidence interval.

$\mathrm{IQR}=$ interquartile range.

ILA = intraoperative local anaesthesia.

$\mathrm{LA}=$ local anaesthetic.

$\mathrm{n}=$ number.

$\mathrm{P}=\mathrm{P}$ value,

${ }^{*}$ re-analysis of reported data.

+studies where supplementary analgesics were given.

TPPPS $=$ Toddler Preschooler-Postoperative Pain Scale.

VAS $=$ visual assessment scale.

Table 5. Infiltration injection LA versus intraligamental injection LA versus no treatment (1 study)

\section{Lignocaine plus adrenaline}

\begin{tabular}{|c|c|c|c|c|c|}
\hline & & LA infiltration & $\begin{array}{l}\text { LA intraligamen- } \\
\text { tal }\end{array}$ & No treatment & \\
\hline Study & Outcome & Treatment & Treatment & Comparator & Results \\
\hline \multirow[t]{5}{*}{ Leong $2007^{+}$} & $\begin{array}{l}\text { Pain/discomfort (STPP- } \\
\text { PS) immediately on } \\
\text { waking }\end{array}$ & $\begin{array}{l}\text { Median } 4 \text { ( } 2.5 \text { to } \\
4.0 \text { IQR) } n=17\end{array}$ & $\begin{array}{l}\text { Median } 4 \text { ( } 2.5 \text { to } \\
5.0 \text { IQR) } n=19\end{array}$ & $\begin{array}{l}\text { Median } 4 \text { ( } 3.8 \text { to } \\
5.0 \text { IQR) } n=18\end{array}$ & $\begin{array}{l}\mathrm{P}=0.32 \text { (Kruskal-Walis } \\
\text { test) }\end{array}$ \\
\hline & $\begin{array}{l}\text { Pain/discomfort (STPP- } \\
\text { PS) } 30 \text { minutes after } \\
\text { waking }\end{array}$ & $\begin{array}{l}\text { Median } 2 \text { ( } 0 \text { to } 4.0 \\
\text { IQR) } n=17\end{array}$ & $\begin{array}{l}\text { Median } 1 \text { ( } 0 \text { to } 3.0 \\
\text { IQR) } n=19\end{array}$ & $\begin{array}{l}\text { Median } 2 \text { ( } 0 \text { to } \\
3.3 \mathrm{IQR} \text { ) } n=18\end{array}$ & $\begin{array}{l}\mathrm{P}=0.73 \text { (Kruskal-Walis } \\
\text { test) }\end{array}$ \\
\hline & $\begin{array}{l}\text { Pain/discomfort (STPP- } \\
\text { PS) first night }\end{array}$ & $\begin{array}{l}\text { Median } 0(0 \text { to } 1.0 \\
\text { IQR) } n=17\end{array}$ & $\begin{array}{l}\text { Median } 0 \text { ( } 0 \text { to } 0 \\
\text { IQR) } n=18\end{array}$ & $\begin{array}{l}\text { Median } 0 \text { ( } 0 \text { to } 0 \\
\text { IQR) } n=17\end{array}$ & $\begin{array}{l}\mathrm{P}=0.036 \text { (Kruskal-Walis } \\
\text { test) }\end{array}$ \\
\hline & $\begin{array}{l}\text { Pain/discomfort (MPDS) } \\
\text { immediately on waking }\end{array}$ & $\begin{array}{l}\text { Median } 4 \text { ( } 1.0 \text { to } \\
4.0 \text { IQR) } n=17\end{array}$ & $\begin{array}{l}\text { Median } 4 \text { ( } 0 \text { to } 4.0 \\
\text { IQR) } n=19\end{array}$ & $\begin{array}{l}\text { Median } 2.5(1.8 \\
\text { to } 4.5 \text { IQR) } n=18\end{array}$ & $\begin{array}{l}P=0.96 \text { (Kruskal-Walis } \\
\text { test) }\end{array}$ \\
\hline & $\begin{array}{l}\text { Pain/discomfort (MPDS) } \\
15 \text { minutes after waking }\end{array}$ & $\begin{array}{l}\text { Median } 1 \text { ( } 0 \text { to } 1.0 \\
\text { IQR) } n=17\end{array}$ & $\begin{array}{l}\text { Median } 0(0 \text { to } 3.0 \\
\text { IQR) } n=19\end{array}$ & $\begin{array}{l}\text { Median } 2 \text { ( } 0 \text { to } 4 \\
\mathrm{IQR}) \mathrm{n}=18\end{array}$ & $\begin{array}{l}P=0.15 \text { (Kruskal-Walis } \\
\text { test) }\end{array}$ \\
\hline
\end{tabular}


Table 5. Infiltration injection LA versus intraligamental injection LA versus no treatment (1 study) (Continued)

\begin{tabular}{lllll}
$\begin{array}{l}\text { Pain/discomfort (MPDS) } \\
30 \text { minutes after waking }\end{array}$ & $\begin{array}{l}\text { Median } 0 \text { (0 to } 1.0 \\
\text { IQR) } n=17\end{array}$ & $\begin{array}{l}\text { Median } 0(0 \text { to } 1 \\
\text { IQR) } n=19\end{array}$ & $\begin{array}{l}\text { Median } 0.5(0 \text { to } \\
\text { I IQR) } n=18\end{array}$ & $\begin{array}{l}\mathrm{P}=0.49 \text { (Kruskal-Walis } \\
\text { test) }\end{array}$ \\
\hline $\begin{array}{l}\text { Postoperative anxiety } \\
\text { (Venham Picture Test) }\end{array}$ & $\begin{array}{l}\text { Median } 5.0(1.5 \text { to } \\
9.0 \mathrm{IQR}) \mathrm{n}=17\end{array}$ & $\begin{array}{l}\text { Median } 9(5.3 \text { to } \\
9.0 \mathrm{IQR}) \mathrm{n}=18\end{array}$ & $\begin{array}{l}\text { Median } 7(4.0 \text { to } \\
9.0 \mathrm{IQR}) \mathrm{n}=17\end{array}$ & $\begin{array}{l}\mathrm{P}=0.23 \text { (Kruskal-Walis } \\
\text { test) (The scale ranges } \\
\text { from 0 to 8, but a score } \\
\text { of } 9 \text { was given if the } \\
\text { child refused to use the } \\
\text { scale) }\end{array}$ \\
& & &
\end{tabular}

$\mathrm{IQR}=$ interquartile range.

$\mathrm{LA}=$ local anaesthetic.

MPDS = modified pain/discomfort scale.

$\mathrm{n}=$ number.

$P=P$ value.

+studies where supplementary analgesics were given.

*re-analysis of reported data.

STPPPS = Simplified Toddler Preschooler-Postoperative Pain Scale.

Table 6. Topical LA versus placebo or no treatment (4 studies)

\begin{tabular}{|c|c|c|c|c|}
\hline \multicolumn{5}{|c|}{ Lignocaine alone (delivered as spray) } \\
\hline Study & Outcome & Treatment & Comparator & Results \\
\hline & & LA & No treatment & \\
\hline \multirow[t]{4}{*}{ Elhakim 1993* } & $\begin{array}{l}\text { Pain (presence or absence) } \\
15 \text { minutes }\end{array}$ & $2 / 20$ & $15 / 20$ & $\mathrm{P}<0.001$ (Fisher's exact test) \\
\hline & $\begin{array}{l}\text { Pain (presence or absence) } \\
30 \text { minutes }\end{array}$ & $1 / 20$ & $11 / 20$ & $P<0.001$ (Fisher's exact test) \\
\hline & $\begin{array}{l}\text { Pain (presence or absence) } \\
60 \text { minutes }\end{array}$ & $2 / 20$ & $9 / 20$ & $P=0.03$ (Fisher's exact test) \\
\hline & Bleeding & - & - & $\begin{array}{l}\text { "There was no early postoperative ad- } \\
\text { verse effects in all groups except for a } \\
\text { greater incidence of prolonged postop- } \\
\text { erative blood oozing in the group C [no } \\
\text { treatment] associated with crying." No } \\
\text { summary statistics reported }\end{array}$ \\
\hline \multicolumn{5}{|c|}{ Bupivacaine plus adrenaline (delivered on a dental swab) } \\
\hline \multirow[t]{2}{*}{ Study } & Outcome & Treatment & Comparator & Results \\
\hline & & LA & Placebo & \\
\hline \multirow[t]{3}{*}{$\begin{array}{l}\text { Andrzejowski } \\
2002^{\star+}\end{array}$} & $\begin{array}{l}\text { Pain (4-category scale) } 15 \\
\text { minutes postoperatively }\end{array}$ & $\begin{array}{l}\text { Median } 1.5(1 \text { to } \\
2 \text { IQR) } n=58\end{array}$ & $\begin{array}{l}\text { Median } 1 \text { ( } 1 \text { to } 3 \\
\text { IQR) } n=62\end{array}$ & $P=0.66$ (Mann Whitney U Test) \\
\hline & $\begin{array}{l}\text { Pain (4-category scale) } 30 \\
\text { minutes postoperatively }\end{array}$ & $\begin{array}{l}\text { Median } 1 \text { ( } 0 \text { to } 2 \\
\text { IQR) } n=58\end{array}$ & $\begin{array}{l}\text { Median } 1 \text { ( } 0 \text { to } 2 \\
\text { IQR) } n=62\end{array}$ & $P=0.46$ (Mann Whitney U Test) \\
\hline & $\begin{array}{l}\text { Bleeding at } 15 \text { and } 30 \text { min- } \\
\text { utes }\end{array}$ & - & - & $\begin{array}{l}\text { "There was no difference in degree of } \\
\text { bleeding between the groups. The aver- }\end{array}$ \\
\hline
\end{tabular}


Table 6. Topical LA versus placebo or no treatment (4 studies) (Continued)

age of the nurse's subjective assessment of bleeding was 'mild' in both groups at $15 \mathrm{~min}$ and 'none' at $30 \mathrm{~min}$ "

\begin{tabular}{|c|c|c|c|c|}
\hline \multirow[t]{2}{*}{ Gazal 2004*+ } & $\begin{array}{l}\text { Distress (5-category faces } \\
\text { scale) postoperatively }\end{array}$ & $\begin{array}{l}\text { Mean } 1.28(1.31 \\
\text { sd) } n=68\end{array}$ & $\begin{array}{l}\text { Mean } 1.56(1.20 \\
\text { sd) } n=67\end{array}$ & $\begin{array}{l}-0.28(95 \% \mathrm{Cl}-0.71 \text { to } 0.15) \mathrm{P}=0.19(\mathrm{t}- \\
\text { Test) }\end{array}$ \\
\hline & $\begin{array}{l}\text { Distress ( } 5 \text {-category faces } \\
\text { scale) } 15 \text { minutes postop- } \\
\text { eratively }\end{array}$ & $\begin{array}{l}\text { Mean } 1.90(1.49 \\
\text { sd) } n=68\end{array}$ & $\begin{array}{l}\text { Mean } 1.96(1.33 \\
\text { sd) } n=67\end{array}$ & $\begin{array}{l}-0.06(95 \% \mathrm{Cl}-0.54 \text { to } 0.42) \mathrm{P}=0.81(\mathrm{t}- \\
\text { Test) }\end{array}$ \\
\hline \multirow[t]{5}{*}{ Quirke 2005} & $\begin{array}{l}\text { Pain (TPPPS) } 5 \text { minutes } \\
\text { postoperatively }\end{array}$ & $\begin{array}{l}\text { Median } 0 \text { ( } 0 \text { to } 7 \\
\text { Range) } n=24\end{array}$ & $\begin{array}{l}\text { Median } 0 \text { ( } 0 \text { to } 7 \\
\text { Range) } n=24\end{array}$ & $\begin{array}{l}\text { "There was no significant difference in } \\
\text { the individual maximum pain scores be- } \\
\text { tween the two groups (Mann Whitney } U \\
\text { Test } P>0.05 \text { )" }\end{array}$ \\
\hline & $\begin{array}{l}\text { Pain (TPPPS) } 10 \text { minutes } \\
\text { postoperatively }\end{array}$ & $\begin{array}{l}\text { Median } 1 \text { ( } 0 \text { to } 8 \\
\text { Range) } n=24\end{array}$ & $\begin{array}{l}\text { Median } 0 \text { ( } 0 \text { to } 7 \\
\text { Range) } n=24\end{array}$ & - \\
\hline & $\begin{array}{l}\text { Pain (TPPPS) } 15 \text { minutes } \\
\text { postoperatively }\end{array}$ & $\begin{array}{l}\text { Median } 0 \text { ( } 0 \text { to } 7 \\
\text { Range) } n=24\end{array}$ & $\begin{array}{l}\text { Median } 0 \text { ( } 0 \text { to } 7 \\
\text { Range) } n=24\end{array}$ & - \\
\hline & $\begin{array}{l}\text { Pain (TPPPS) } 30 \text { minutes } \\
\text { postoperatively }\end{array}$ & $\begin{array}{l}\text { Median } 1 \text { ( } 0 \text { to } 7 \\
\text { Range) } n=24\end{array}$ & $\begin{array}{l}\text { Median } 0 \text { ( } 0 \text { to } 5 \\
\text { Range) } n=24\end{array}$ & - \\
\hline & $\begin{array}{l}\text { Pain (TPPPS) combined } \\
\text { over all } 4 \text { time points }\end{array}$ & $\begin{array}{l}\text { Median } 1.5 \text { ( } 0 \text { to } \\
29 \text { Range) } n=24\end{array}$ & $\begin{array}{l}\text { Median } 1 \text { ( } 0 \text { to } 25 \\
\text { Range) } n=24\end{array}$ & $\begin{array}{l}\text { "...no significant difference between the } \\
\text { two groups }(P>0.05) "\end{array}$ \\
\hline
\end{tabular}

$\mathrm{Cl}=$ confidence interval.

$\mathrm{IQR}=$ interquartile range.

$\mathrm{LA}=$ local anaesthetic.

$\mathrm{n}=$ number.

$\mathrm{P}=\mathrm{P}$ value

$\mathrm{SD}=$ standard deviation

+studies where supplementary analgesics were given.

${ }^{*}$ re-analysis of reported data.

TPPPS $=$ Toddler Preschooler-Postoperative Pain Scale.

\section{AP PEN DICES}

\section{Appendix 1. MEDLINE (Ovid) Search Strategy}

1. $\exp$ DENTISTRY/

2. (dental\$ or dentist\$).ti,ab.

3. (oral adj5 surg\$).ti,ab.

4. (orthodontic $\$$ or pulpotom\$ or pulpect\$ or endodont\$ or "pulp cap\$").mp.

5. ((dental or tooth or teeth) adj5 (fill\$ or restor\$ or extract\$ or remov\$ or "cavity prep\$" or caries or carious or decay\$)).mp.

6. (root canal and (therap\$ or treat\$)).mp.

7. (tooth adj3 replant\$).mp.

8. or/1-7

9. Anesthetics, Local/

10.Anesthesia, Local/

11.(local adj5 (anesthetic\$ or anaesthetic\$ or anesthesia or anaesthesia)).mp.

12.Lidocaine/

13. (lidocaine or lignocaine or xylocaine).mp. 
14.Carticaine/

15. (carticain\$ or articain\$).mp.

16.Prilocaine/

17. (prilocain\$ or citanest\$ or propitocain\$ or xylonest).mp.

18. Bupivacaine/

19. (bupivacain\$ or buvacaina or carbostesin or dolanaest or marcain\$ or sensorcain\$ or svedocain\$).mp.

20.or/9-19

21.exp Anesthesia, General/

22.exp Anesthetics, General/

23. (general adj5 (anesthetic\$ or anaesthetic\$ or anesthesia or anaesthesia)).mp.

24.(sevofluran\$ or ultane or sevorane or "fluoromethyl hexafluoroisopropyl ether").mp.

25. Halothane/

26.(halothane or fluothane or florotan or narcotan).mp.

27. Nitrous oxide/

28.("nitrous oxide" or "nitrogen protoxide" or "laughing gas").mp.

29.Isoflurane/

30.isofluran\$.mp.

31. Enflurane/

32. (enflurane or alyrane or enfran or enlirane or ethrane or etran).mp.

33. Ketamine/

34.(ketamin\$ or calipsol or calypsol or kalipsol or ketalar or ketanest or ketaset).mp.

35. Midazolam/

36.(midazolam or dormicum).mp.

37.Lorazepam/

38. (lorazepam or ativan or donix or duralozam or durazolam or idalprem or laubeel or lorazp or noro-lorazem or nu-loraz or "orfidal wyeth" or sinestron or somagerol or temestra).mp.

39.Xenon/

40.xenon.mp.

41. Thiopenton/

42. (thiopenton\$ or thiopental or bomathal or nesdonal or penthiobarbital or pentothal or sodipental or thiomebumal or thionembutal or thiopentobarbital or trapanal or "tiobarbital braun").mp.

43. Methohexital/

44.(methohexital or "brevimytal natrum" or brevital or brietal or methohexitone).mp.

45.Diazepam/

46.(diazepam or apaurin or diazemuls or faustan or relanium or seduxen or sidazon or stesolid or valium).mp.

47.Propofol/

48. (propofol or aquafol or diprivan or disoprival or disoprofol or fresofol or ivofol or recofol).mp.

49.or/21-48

50.exp Child/

51.Infant/

52.Adolescent/

53. (child\$ or infant\$ or adolescen\$ or teenage $\$$ or preteen $\$$ or pre-teen\$).mp.

54.(pediatric $\$$ or paediatric\$).mp.

55.Dental care for children/

56.or/50-55

57.8 and 20 and 49 and 56

\section{Appendix 2. Cochrane Oral Health Group Trials Register Search Strategy}

\#1 ((local and (anesthetic* or anaesthetic* or anesthesia or anaesthesia)):ti,ab) AND (INREGISTER)

\#2 ((lidocaine or lignocaine or xylocaine):ti,ab) AND (INREGISTER)

\#3 ((carticain* or articain*):ti,ab) AND (INREGISTER)

\#4 ((prilocain ${ }^{\star}$ or citanest ${ }^{\star}$ or propitocain* or xylonest):ti,ab) AND (INREGISTER)

\#5 ((bupivacain* or buvacaina or carbostesin or dolanaest or marcain* or sensorcain* or svedocain $\left.\left.{ }^{\star}\right): t i, a b\right)$ AND (INREGISTER)

Intraoperative local anaesthesia for reduction of postoperative pain following general anaesthesia for dental treatment in children and 
\#6 (\#1 or \#2 or \#3 or \#4 or \#5) AND (INREGISTER)

\#7 ((general and (anesthetic ${ }^{\star}$ or anaesthetic ${ }^{\star}$ or anesthesia or anaesthesia)):ti,ab) AND (INREGISTER)

\#8 ((sevofluran* or ultane or sevorane or "fluoromethyl hexafluoroisopropyl ether"):ti,ab) AND (INREGISTER)

\#9 ((halothane or fluothane or florotan or narcotan):ti,ab) AND (INREGISTER)

\#10 (("nitrous oxide" or "nitrogen protoxide" or "laughing gas"):ti,ab) AND (INREGISTER)

\#11 (isofluran*:ti,ab) AND (INREGISTER)

\#12 ((enflurane or alyrane or enfran or enlirane or ethrane or etran):ti,ab) AND (INREGISTER)

\#13 ((ketamin ${ }^{\star}$ or calipsol or calypsol or kalipsol or ketalar or ketanest or ketaset):ti,ab) AND (INREGISTER)

\#14 ((midazolam or dormicum):ti,ab) AND (INREGISTER)

\#15 ((lorazepam or ativan or donix or duralozam or durazolam or idalprem or laubeel or lorazp or noro-lorazem or nu-loraz or "orfidal

wyeth" or sinestron or somagerol or temestra):ti,ab) AND (INREGISTER)

\#16 (xenon:ti,ab) AND (INREGISTER)

\#17 ((thiopenton* or thiopental or bomathal or nesdonal or penthiobarbital or pentothal or sodipental or thiomebumal or thionembutal or thiopentobarbital or trapanal or "tiobarbital braun"):ti,ab) AND (INREGISTER)

\#18 ((methohexital or "brevimytal natrum" or brevital or brietal or methohexitone):ti,ab) AND (INREGISTER)

\#19 ((diazepam or apaurin or diazemuls or faustan or relanium or seduxen or sidazon or stesolid or valium):ti,ab) AND (INREGISTER)

\#20 ((propofol or aquafol or diprivan or disoprival or disoprofol or fresofol or ivofol or recofol):ti,ab) AND (INREGISTER)

$\# 21$ (\#7 or \#8 or \#9 or \#10 or \#11 or \#12 or \#13 or \#14 or \#15 or \#16 or \#17 or \#18 or \#19 or \#20) AND (INREGISTER)

\#22 ((child ${ }^{\star}$ or infant $^{\star}$ or adolescen ${ }^{\star}$ or teenage* or preteen $^{\star}$ or pre-teen $\left.{ }^{\star}\right)$ :ti,ab) AND (INREGISTER)

\#23 ((pediatric* or paediatric*):ti,ab) AND (INREGISTER)

\#24 (\#22 or \#23) AND (INREGISTER)

$\# 25$ (\#6 and \#21 and \#24) AND (INREGISTER)

\section{Appendix 3. Cochrane Central Register of Controlled Trials (CENTRAL) Search Strategy}

\#1 MeSH descriptor: [Dentistry] explode all trees

\#2 (oral near/5 surg*):ti,ab

\#3 (dental ${ }^{\star}$ or dentist*):ti,ab

\#4 (orthodontic* or pulpotom* or pulpect* or endodont* or "pulp cap*"):ti,ab

\#5 ((dental or tooth or teeth) near/5 (fill* or restor ${ }^{\star}$ or extract ${ }^{\star}$ or remov* or "cavity prep ${ }^{\star}$ or caries or carious or decay $\left.{ }^{\star}\right)$ :ti,ab

\#6 (root canal and (therap* or treat*)):ti,ab

$\# 7$ (tooth near/3 replant $\left.{ }^{\star}\right): \mathrm{ti}, \mathrm{ab}$

\#8 \#1 or \#2 or \#3 or \#4 or \#5 or \#6 or \#7

\#9 MeSH descriptor: [Anesthetics, Local] this term only

$\# 10$ MeSH descriptor: [Anesthesia, Local] this term only

\#11 (local near/5 (anesthetic ${ }^{\star}$ or anaesthetic* or anesthesia or anaesthesia)):ti,ab

$\# 12 \mathrm{MeSH}$ descriptor: [Lidocaine] this term only

\#13 (lidocaine or lignocaine or xylocaine):ti,ab

\#14 MeSH descriptor: [Carticaine] this term only

\#15 (carticain* or articain*):ti,ab

\#16 MeSH descriptor: [Prilocaine] this term only

\#17 (prilocain* or citanest* or propitocain* or xylonest):ti,ab

\#18 MeSH descriptor: [Bupivacaine] this term only

\#19 (bupivacain* or buvacaina or carbostesin or dolanaest or marcain ${ }^{\star}$ or sensorcain* or svedocain ${ }^{\star}$ ):ti,ab

$\# 20 \# 9$ or \#10 or \#11 or \#12 or \#13 or \#14 or \#15 or \#16 or \#17 or \#18 or \#19

\#21 MeSH descriptor: [Anesthesia, General] explode all trees

\#22 MeSH descriptor: [Anesthetics, General] explode all trees

\#23 (general near/5 (anesthetic* or anaesthetic* or anesthesia or anaesthesia)):ti,ab

\#24 (sevofluran* or ultane or sevorane or "fluoromethyl hexafluoroisopropyl ether"):ti,ab

\#25 MeSH descriptor: [Halothane] this term only

\#26 (halothane or fluothane or florotan or narcotan):ti,ab

\#27 MeSH descriptor: [Nitrous Oxide] this term only

\#28 ("nitrous oxide" or "nitrogen protoxide" or "laughing gas"):ti,ab

\#29 MeSH descriptor: [Isoflurane] this term only

\#30 isofluran*:ti,ab

\#31 MeSH descriptor: [Enflurane] this term only

\#32 (enflurane or alyrane or enfran or enlirane or ethrane or etran):ti,ab

\#33 MeSH descriptor: [Ketamine] this term only

\#34 (ketamin* or calipsol or calypsol or kalipsol or ketalar or ketanest or ketaset):ti,ab

\#35 MeSH descriptor: [Midazolam] this term only

\#36 (midazolam or dormicum):ti,ab

\#37 MeSH descriptor: [Lorazepam] this term only

Intraoperative local anaesthesia for reduction of postoperative pain following general anaesthesia for dental treatment in children and 
\#38 (lorazepam or ativan or donix or duralozam or durazolam or idalprem or laubeel or lorazp or noro-lorazem or nu-loraz or "orfidal wyeth" or sinestron or somagerol or temestra):ti,ab

\#39 MeSH descriptor: [Xenon] explode all trees

\#40 xenon:ti,ab

\#41 MeSH descriptor: [Thiopental] this term only

\#42 (thiopenton* or thiopental or bomathal or nesdonal or penthiobarbital or pentothal or sodipental or thiomebumal or thionembutal or thiopentobarbital or trapanal or "tiobarbital braun"):ti,ab

\#43 MeSH descriptor: [Methohexital] this term only

\#44 (methohexital or "brevimytal natrum" or brevital or brietal or methohexitone):ti,ab

\#45 MeSH descriptor: [Diazepam] this term only

\#46 (diazepam or apaurin or diazemuls or faustan or relanium or seduxen or sidazon or stesolid or valium):ti,ab

\#47 MeSH descriptor: [Propofol] this term only

\#48 (propofol or aquafol or diprivan or disoprival or disoprofol or fresofol or ivofol or recofol):ti,ab

$\# 49 \# 21$ or \#22 or \#23 or \#24 or \#25 or \#26 or \#27 or \#28 or \#29 or \#30 or \#31 or \#32 or \#33 or \#34 or \#35 or \#36 or \#37 or \#38 or \#39 or \#40 or \#41 or \#42 or \#43 or \#44 or \#45 or \#46 or \#47 or \#48

\#50 (child* or infant $^{\star}$ or adolescen* or teenage* $^{\star}$ or preteen ${ }^{\star}$ or pre-teen $\left.{ }^{\star}\right): t i, a b$

$\# 51$ \#8 and \#20 and \#49 and \#50

\section{Appendix 4. EMBASE (OVID) Search Strategy}

1. exp DENTISTRY/

2. (dental\$ or dentist\$).ti,ab.

3. (oral adj5 surg\$).ti,ab.

4. (orthodontic\$ or pulpotom\$ or pulpect\$ or endodont\$ or "pulp cap\$").mp.

5. ((dental or tooth or teeth) adj5 (fill\$ or restor\$ or extract\$ or remov\$ or "cavity prep\$" or caries or carious or decay\$)).mp.

6. (root canal and (therap\$ or treat\$)).mp.

7. (tooth adj3 replant\$).mp.

8. or/1-7

9. Local anesthetic agent/

10. Local anesthesia/

11.(local adj5 (anesthetic\$ or anaesthetic\$ or anesthesia or anaesthesia)).mp.

12.Lidocaine/

13.(lidocaine or lignocaine or xylocaine).mp.

14.Articaine/

15. (carticain\$ or articain\$).mp.

16.Prilocaine/

17. (prilocain\$ or citanest\$ or propitocain\$ or xylonest).mp.

18. Bupivacaine/

19. (bupivacain\$ or buvacaina or carbostesin or dolanaest or marcain\$ or sensorcain\$ or svedocain\$).mp.

20.or/9-19

21.exp General anesthesia/

22.exp Anesthetic Agent/

23. (general adj5 (anesthetic\$ or anaesthetic\$ or anesthesia or anaesthesia)).mp.

24.(sevofluran\$ or ultane or sevorane or "fluoromethyl hexafluoroisopropyl ether").mp.

25. Halothane/

26.(halothane or fluothane or florotan or narcotan).mp.

27. Nitrous oxide/

28.("nitrous oxide" or "nitrogen protoxide" or "laughing gas").mp.

29.Isoflurane/

30.isofluran\$.mp.

31. Enflurane/

32.(enflurane or alyrane or enfran or enlirane or ethrane or etran).mp.

33. Ketamine/

34. (ketamin\$ or calipsol or calypsol or kalipsol or ketalar or ketanest or ketaset).mp.

35. Midazolam/

36.(midazolam or dormicum).mp.

Intraoperative local anaesthesia for reduction of postoperative pain following general anaesthesia for dental treatment in children and 
37.Lorazepam/

38. (lorazepam or ativan or donix or duralozam or durazolam or idalprem or laubeel or lorazp or noro-lorazem or nu-loraz or "orfidal wyeth" or sinestron or somagerol or temestra).mp.

39.Xenon/

40.xenon.mp.

41.Thiopental/

42. (thiopenton\$ or thiopental or bomathal or nesdonal or penthiobarbital or pentothal or sodipental or thiomebumal or thionembutal or thiopentobarbital or trapanal or "tiobarbital braun").mp.

43. Methohexital/

44.(methohexital or "brevimytal natrum" or brevital or brietal or methohexitone).mp.

45.Diazepam/

46. (diazepam or apaurin or diazemuls or faustan or relanium or seduxen or sidazon or stesolid or valium).mp.

47.Propofol/

48.(propofol or aquafol or diprivan or disoprival or disoprofol or fresofol or ivofol or recofol).mp.

49.or/21-48

50.exp Child/

51.Infant/

52.Adolescent/

53. (child\$ or infant\$ or adolescen\$ or teenage $\$$ or preteen $\$$ or pre-teen\$).mp.

54. (pediatric\$ or paediatric\$).mp.

55.Dental care for children/

56. or $/ 50-55$

57.8 and 20 and 49 and 56

\section{Appendix 5. Web of Science Conference Proceedings Search Strategy}

\section{\# 30 \#7 AND \#13 AND \#28 AND \#29}

\# 29 TS=(child ${ }^{\star}$ or infant ${ }^{\star}$ or adolescen ${ }^{\star}$ or teenage ${ }^{\star}$ or preteen ${ }^{\star}$ or pre-teen ${ }^{\star}$ )

$\# 28 \# 14$ or \#15 or \#16 or \#17 or \#18 or \#19 or \#20 or \#21 or \#22 or \#23 or \#24 or \#25 or \#26 or \#27

\# $27 \mathrm{TS}=$ (propofol or aquafol or diprivan or disoprival or disoprofol or fresofol or ivofol or recofol)

\# 26 TS=(diazepam or apaurin or diazemuls or faustan or relanium or seduxen or sidazon or stesolid or valium)

\# 25 TS=(methohexital or "brevimytal natrum" or brevital or brietal or methohexitone)

\# 24 TS=(thiopenton* or thiopental or bomathal or nesdonal or penthiobarbital or pentothal or sodipental or thiomebumal or thionembutal or thiopentobarbital or trapanal or "tiobarbital braun")

\# $23 \mathrm{TS}=$ xenon

\# 22 TS=(lorazepam or ativan or donix or duralozam or durazolam or idalprem or laubeel or lorazp or noro-lorazem or nu-loraz or "orfidal wyeth" or sinestron or somagerol or temestra)

\# $21 \mathrm{TS}=$ (midazolam or dormicum)

\# 20 TS=(ketamin* or calipsol or calypsol or kalipsol or ketalar or ketanest or ketaset)

\# 19 TS=(enflurane or alyrane or enfran or enlirane or ethrane or etran)

\# 18 TS=isofluran*

\# 17 TS=("nitrous oxide" or "nitrogen protoxide" or "laughing gas")

\# 16 TS=(halothane or fluothane or florotan or narcotan)

\# 15 TS=(sevofluran* or ultane or sevorane or "fluoromethyl hexafluoroisopropyl ether")

\# 14 TS=(general AND (anesthetic* or anaesthetic ${ }^{*}$ or anesthesia or anaesthesia))

\# 13 \# 8 or \#9 or \#10 or \#11 or \#12

\# 12 TS=(bupivacain* or buvacaina or carbostesin or dolanaest or marcain* or sensorcain ${ }^{\star}$ or svedocain*)

\# 11 TS=(prilocain* or citanest* or propitocain* or xylonest).

\# $10 \mathrm{TS}=\left(\right.$ carticain $^{\star}$ or articain $\left.^{\star}\right)$

\# 9 TS=(lidocaine or lignocaine or xylocaine)

\# 8 TS=(local AND (anesthetic ${ }^{\star}$ or anaesthetic* or anesthesia or anaesthesia))

\# 7 \#1 or \#2 or \#3 or \#4 or \#5 or \#6

\# 6 TS=(tooth AND replant ${ }^{\star}$ )

\# 5 TS=("root canal" and (therap* or treat*))

\# 4 TS=((dental or tooth or teeth) AND (fill* or restor* or extract* or remov* or "cavity prep*" or caries or carious or decay $\left.\left.{ }^{\star}\right)\right)$

\# 3 TS=(orthodontic* or pulpotom* or pulpect* or endodont* or "pulp cap*")

\# 2 TS $=\left(\right.$ dental $^{*}$ or dentist $\left.{ }^{\star}\right)$

\# 1 TS=(oral and surg*)

Intraoperative local anaesthesia for reduction of postoperative pain following general anaesthesia for dental treatment in children and 


\section{Appendix 6. US National Institutes of Health Register (ClinicalTrials.gov) Search Strategy}

intraoperative anaesthesia AND dental or teeth or tooth or "oral surg*"

intraoperative anesthesia AND dental or teeth or tooth or "oral surg"

\section{Appendix 7. metaRegister of Controlled Trials (mRCT) Search Strategy}

intraoperative AND anesthesia AND dental AND child*

intraoperative AND anaesthesia AND dental AND child*

Appendix 8. International Federation of Pharmaceutical Manufacturers \& Associations (IFPMA) Clinical Trials Portal Search Strategy

intraoperative anesthesia

intraoperative anaesthesia

\section{Appendix 9. Data extraction form}

Preoperative local anaesthesia for additional pain relief in children, adolescents, and adults receiving dental treatment

DATA EXTRACTION FORM

\section{Study ID}

\section{First author}

Reviewer ID

Year of publication

Title (first 5 words)

Country of study

Verification of study eligibility/category

\section{Children/adolescents/adults having dental treatment under GA}

\section{Primary outcome(s) of interest reported}

\section{Study designed as RCT}

Primary outcomes are

Differences in preoperative and postoperative pain measures between test and control groups

Study eligible? Yes No

(no to any of above renders study ineligible. Unclear renders study eligible until further clarified).

Comments:

\section{QUALITY assessment}




\begin{tabular}{l}
\hline \\
\hline Was a sample size calculation reported? \\
\hline Was method of generation of randomised sequence ade- \\
quate? \\
(Yes = generated by random number table, tossed coin, and \\
shuffled cards) \\
(No = alternate assignment, hospital number, and odd/even \\
DOB) \\
(Unclear = reference to randomisation but method not re- \\
ported or inadequately explained)
\end{tabular}

\section{Was Allocation concealment adequate?}

(Yes = central registrar, sequentially coded containers, sequentially coded opaque envelopes)

(No =randomisation not concealed (e.g., alternate assignment, hosp. no., odd/even DOB) or not reported

(Unclear = reference to allocation concealment but method not reported or inadequately explained)

\section{Was the patient blind to the therapy?}

Was the operator blind to the therapy?

\section{Was the assessor blind to the therapy?}

Were Inclusion and exclusion criteria clearly defined in the text?

Did the text state there were no withdrawals?

Were outcomes of participants who withdrew or were excluded after allocation detailed separately?

Were outcomes of participants who withdrew or were excluded after allocation included in an intention-to-treat analysis?

\section{Were treatment and control groups described at entry?}

Was the use of an intention-to-treat analysis stated?

\section{Study characteristics}

Source of funding: Academic Govt Non-govt Industry Unclear Year trial conducted: ____, Unclear Number of centres in trial: _______, Unclear

Did the study report that ethical approval was obtained: Yes No Did the study report that informed consent was obtained: Yes No 


\section{Population characteristics}

Where were the participants recruited?

Uni/Hosp GDP Practice Paed Speciality Practice Unclear

Previous dental treatment of participant: $\quad$ Yes No Unclear

Interventions

\begin{tabular}{|c|c|c|c|c|c|c|}
\hline Intervention & $\begin{array}{l}\text { Local anaes- } \\
\text { thetic (specify) }\end{array}$ & Volume & $\begin{array}{l}\text { Method de- } \\
\text { livery }\end{array}$ & $\begin{array}{l}\text { Anaesthet- } \\
\text { ic agent }\end{array}$ & Volume & $\begin{array}{l}\text { Other analgesics (specify } \\
\text { type, route of administra- } \\
\text { tion, and dose) }\end{array}$ \\
\hline
\end{tabular}

\section{Control Group}

Test 1

\section{Test 2}

\section{Test 3}

\section{Sample}

\begin{tabular}{lllll}
\hline Intervention & $\mathrm{N}$ at start & $\mathrm{m} / \mathrm{f}$ & age & $\mathrm{N}$ at end \\
\hline Control Group & & \\
\hline Test 1 & \\
\hline Test 2 & \\
\hline Test 3
\end{tabular}

\section{Other variables}

\begin{tabular}{lll}
\hline Intervention & Bleeding & Quality of GA \\
\hline Control Group & Reason for GA \\
\hline Test 1 & \\
\hline Test 2 & \\
\hline Test 3 & \\
\hline
\end{tabular}

\section{Outcomes}


Intervention

Index used
Outcome - please describe nature of data - e.g., mean differences between groups, etc., and any assessment of variability (e.g., sd, se, $95 \% \mathrm{Cl}$, etc.)

\section{Control}

Test 1

Test 2

\section{Test 3}

Statistical analysis used

\section{Please complete at end of data extraction:}

Possible duplicate report: $\quad$ Yes No

Author contact recommended: Yes No

Additional comments about study:

Need some more information about the ga - what kind of anaesthetic agent, etc.

Intraoperative local anaesthesia for reduction of postoperative pain following general anaesthesia for dental treatment in children and

Copyright $\odot 2019$ The Cochrane Collaboration. Published by John Wiley \& Sons, Ltd. 
Need some more info about the dental treatment - number of teeth , restored, extracted, etc.

WHAT'S NEW

\begin{tabular}{lll}
\hline Date & Event & Description \\
\hline 21 November 2019 & Review declared as stable & $\begin{array}{l}\text { This Cochrane Review is currently not a priority for updating. } \\
\text { However, following the results of Cochrane Oral Health's latest } \\
\text { priority setting exercise and if a substantial body of evidence on } \\
\text { the topic becomes available, the review would be updated in the } \\
\text { future. }\end{array}$ \\
& & \\
\hline
\end{tabular}

\section{CONTRIBUTIONS OF AUTHORS}

Susan Parekh, Collette Gardener, Tanya Walsh, and Paul Ashley were responsible for preparation of the review, data extraction, and writing up.

\section{DECLARATIONS OF INTEREST}

Susan Parekh: nothing to declare.

Collette Gardener: nothing to declare.

Paul F Ashley: Paul Ashley was an author on one of the included studies (Leong 2007). He was not involved in the data extraction or any other decisions regarding this study.

Tanya Walsh: nothing to declare.

\section{SOURCES OF SUPPORT}

\section{Internal sources}

- No sources of support supplied

\section{External sources}

- British Orthodontic Society (BOS), UK.

The BOS have provided funding for Cochrane Oral Health Global Alliance (see www.ohg.cochrane.org).

- New York University (NYU), USA.

NYU have provided funding for Cochrane Oral Health Global Alliance (see www.ohg.cochrane.org).

- British Society of Paediatric Dentistry (BSPD), UK.

The BSPD have provided funding for Cochrane Oral Health Global Alliance (see www.ohg.cochrane.org).

- National Institute for Health Research (NIHR), UK.

This project was supported by the NIHR, via Cochrane Infrastructure funding to Cochrane Oral Health. The views and opinions expressed are those of the authors and not necessarily those of the Systematic Reviews Programme, NIHR, NHS or the Department of Health and Social Care.

\section{DIFFERENCES BETWEEN PROTOCOLANDREVIEW}

The protocol indicated that only LA versus placebo or no LA was the stated comparison. In the published review, we added a comparison of active interventions (another local anaesthetic (including the type, dose, and method)). None of the included studies evaluated this comparison.

We removed preoperative anxiety as an outcome measure. This is an important baseline factor and is included in the 'Characteristics of included studies' tables where it has been measured and reported in a study.

The protocol stated that we would carry out a subgroup analysis with method of LA administration as a source of variation. Once we included the studies in the review, we decided that structuring the review according to method of LA administration was of most value to the clinician and provided greatest clarity to the reader. We acknowledge that this is a departure from the original protocol. Should sufficient studies allow, then we will investigate the subgroup analyses stated in the protocol within this structure. 
We added age categories for the subgroup analysis for the review as this was not made explicit in the protocol. This was done to clarify how we would implement the subgroups.

\section{NOTES}

This Cochrane Review is currently not a priority for updating. However, following the results of Cochrane Oral Health's latest priority setting exercise and if a substantial body of evidence on the topic becomes available, the review would be updated in the future.

\section{IN DEX TERMS}

\section{Medical Subject Headings (MeSH)}

*Anesthesia, General; *Anesthesia, Local; Anesthetics, Local [ ${ }^{\star}$ administration \& dosage]; Bupivacaine; Dental Care [*adverse effects]; Epinephrine; Felypressin; Intraoperative Care [methods]; Lidocaine; Pain, Postoperative [ ${ }^{*}$ prevention \& control]; Postoperative Hemorrhage [prevention \& control]; Prilocaine; Randomized Controlled Trials as Topic

\section{MeSH check words}

Adolescent; Child; Humans 